\title{
A novel approach to the discovery of anti-tumor pharmaceuticals: searching for activators of liponecrosis
}

\author{
Anthony Arlia-Ciommo ${ }^{1}$, Veronika Svistkova ${ }^{1}$, Sadaf Mohtashami ${ }^{1}$ and Vladimir I. \\ Titorenko ${ }^{1}$ \\ ${ }^{1}$ Department of Biology, Concordia University, Montreal, Quebec, Canada \\ Correspondence to: Vladimir I. Titorenko, email: vladimir.titorenko@concordia.ca \\ Keywords: cancer, anti-cancer therapeutics, lipid metabolism, programmed cell death, liponecrosis, yeast \\ Received: August 20, $2015 \quad$ Accepted: November 21, $2015 \quad$ Published: November 30, 2015
}

\section{ABSTRACT}

A recently conducted chemical genetic screen for pharmaceuticals that can extend longevity of the yeast Saccharomyces cerevisiae has identified lithocholic acid as a potent anti-aging molecule. It was found that this hydrophobic bile acid is also a selective anti-tumor chemical compound; it kills different types of cultured cancer cells if used at concentrations that do not compromise the viability of non-cancerous cells. These studies have revealed that yeast can be successfully used as a model organism for high-throughput screens aimed at the discovery of selectively acting anti-tumor small molecules. Two metabolic traits of rapidly proliferating fermenting yeast, namely aerobic glycolysis and lipogenesis, are known to be similar to those of cancer cells. The mechanisms underlying these key metabolic features of cancer cells and fermenting yeast have been established; such mechanisms are discussed in this review. We also suggest how a yeast-based chemical genetic screen can be used for the high-throughput development of selective anti-tumor pharmaceuticals that kill only cancer cells. This screen consists of searching for chemical compounds capable of increasing the abundance of membrane lipids enriched in unsaturated fatty acids that would therefore be toxic only to rapidly proliferating cells, such as cancer cells and fermenting yeast.

\section{INTRODUCTION}

Many pharmaceuticals that are currently used or undergoing clinical evaluation for cancer therapy have been developed as modulators of certain metabolic processes in cancer cells. These processes include the following: (1) nucleotide synthesis; (2) amino acid metabolism; (3) aerobic glycolysis, which is also known as "the Warburg effect"; (4) lipogenesis, a de novo synthesis of bulk quantities of membrane lipids; (5) a lipolytic formation of fatty acids from monoacylglycerols; (6) mitochondrial transport and oxidation of fatty acids; (7) pentose phosphate pathway; and (8) mitochondrial tricarboxylic acid (TCA) cycle and electron transport chain (ETC) [1-10]. A body of evidence implies that at least two of these processes, aerobic glycolysis and lipogenesis, are common metabolic features of cancer cells and rapidly proliferating cells of the yeast Saccharomyces cerevisiae [11-20]. Thus, S. cerevisiae, a unicellular eukaryote amenable to comprehensive molecular analyses [21, 22], can be used as a model organism for the discovery of selective anti-tumor small molecules that target aerobic glycolysis or lipogenesis [19, 23-32]. In this review, we compare molecular and cellular mechanisms underlying aerobic glycolysis and lipogenesis in cancer cells and rapidly proliferating fermenting yeast. Based on our analysis, we propose a novel yeast-based chemical genetic screen for anti-tumor pharmaceuticals that kill cancer cells if used at concentrations that do not compromise functionality and viability of non-cancerous cells. This high-throughput screen is aimed at the identification of small molecules capable of increasing the fatty acid desaturation index of membrane lipids in fermenting yeast cells, thereby eliciting their liponecrotic death. 


\section{LIPONECROSIS IN YEAST: A CELL DEATH PROGRAM CAUSED BY CHANGES IN MEMBRANE LIPIDS}

Our recent studies in the yeast $S$. cerevisiae have discovered and characterized a previously unknown form of programmed cell death (PCD) called "liponecrosis" [25, 33-35]. Liponecrotic PCD can be instigated by a short-term exposure of yeast to exogenous palmitoleic acid (POA), a 16-carbon monounsaturated fatty acid $(16: 1 \mathrm{n}-7)$ [25]. Yeast cells undergoing liponecrotic PCD do not display morphological and biochemical hallmarks of the well-characterized apoptotic, autophagic or regulated necrotic forms of PCD. Indeed, unlike cell commitment to apoptotic PCD known to be accompanied by fragmentation of the nucleus and externalization of phosphatidylserine (PS) within the plasma membrane
(PM) bilayer [36, 37], the commitment of yeast to the liponecrotic form of PCD does not involve nuclear fragmentation or PS enrichment in the extracellular (outer) leaflet of the PM [25, 35]. Furthermore, in contrast to cells undergoing autophagic PCD and therefore accumulating an excessive number of double-membraned vesicles called autophagosomes [36, 38-40], yeast cells that undergo liponecrotic PCD do not display such vast autophagic vacuolization of the cytoplasm [35]. Moreover, contrary to cells undergoing regulated necrotic $\mathrm{PCD}$, which is characterized by a clearly visible rupture of the PM [41-44], yeast cells committed to liponecrotic PCD do not exhibit any noticeable perforations in the PM [35]. However, the necrotic and liponecrotic forms of PCD share at least one common trait - i.e., a substantial rise in the permeability of the PM for propidium iodide (PI) and other small molecules [25, 35, 41, 43, 44].

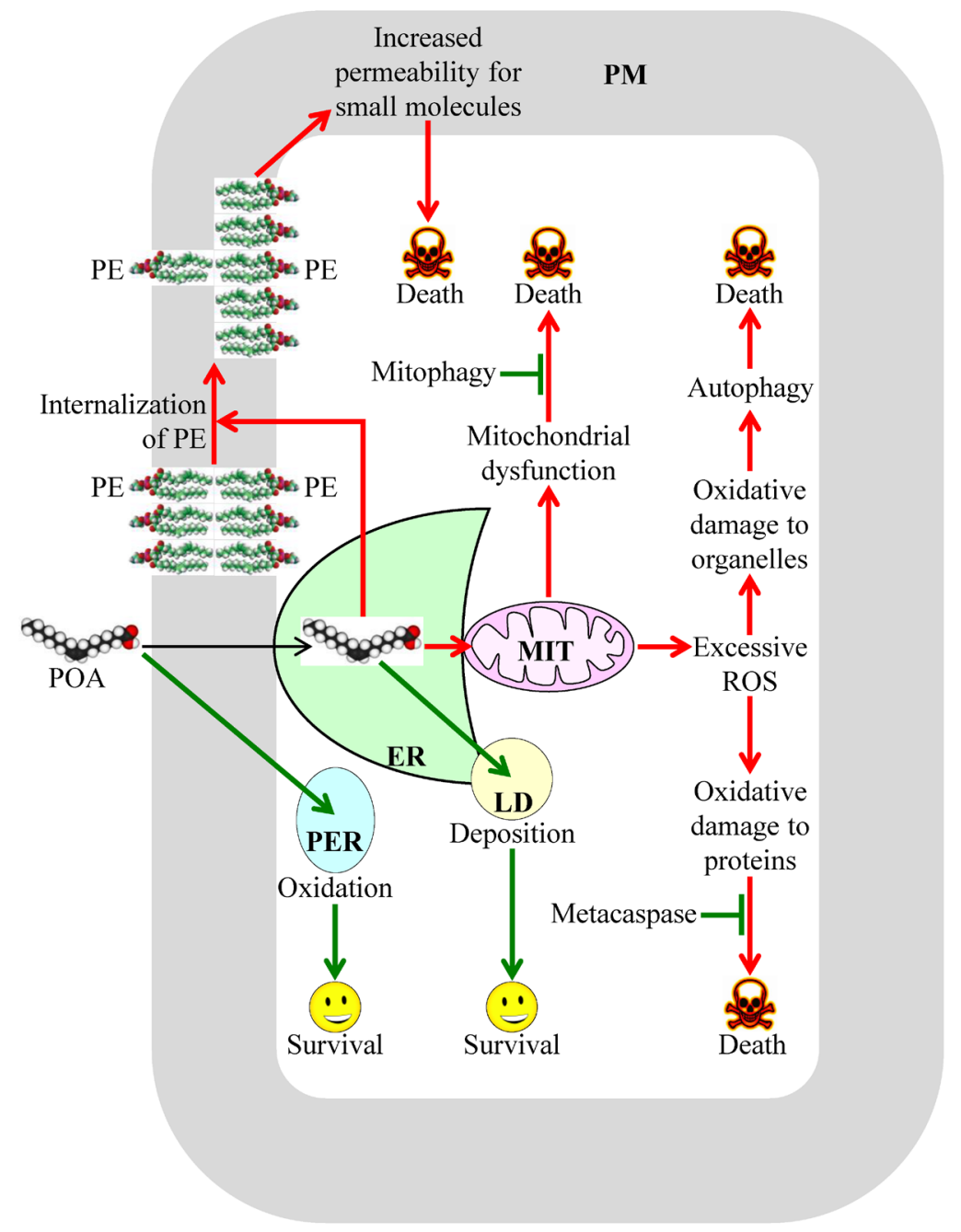

Figure 1: A model for the molecular mechanism underlying a liponecrotic form of programmed cell death (PCD) in yeast. A brief exposure of yeast to exogenously added palmitoleic acid (POA) can trigger liponecrotic PCD, which differs from all other presently known programs of cell death. Liponecrosis in yeast is caused by a massive remodeling of lipid metabolism and lipid transport in the endoplasmic reticulum (ER), peroxisomes (PER), plasma membrane (PM), lipid droplets (LD) and mitochondria (MIT). Activation arrows and inhibition bars denote pro-death cellular processes (which are displayed in red color) or pro-survival cellular processes (which are displayed in green color). See text for more details. Abbreviations: PE, phosphatidylethanolamine; ROS, reactive oxygen species. 
The molecular mechanism underlying liponecrosis has begun to emerge; it is driven by an extensive remodeling of lipid metabolism and lipid transport in yeast cells briefly exposed to exogenous POA [34, 35]. A model for such mechanism is depicted schematically in Figure 1. The model posits that the extent of yeast susceptibility to liponecrotic PCD depends on the relative rates of prodeath and pro-survival cellular processes. In Figure 1 these processes are displayed in red or green color, respectively.

The pro-death cellular processes accelerating liponecrotic PCD can create the acute cellular stress. These processes are elicited when exogenously added POA is initially used for the synthesis of POAcontaining phospholipids in the endoplasmic reticulum (ER); the bulk quantities of these phospholipids then accumulate in the membrane bilayers of mitochondria and PM [34, 35], likely after being transported from the ER to these membrane bilayers via mitochondria-ER and PM-ER junctions (Figure 1) [45-48]. The buildup of POA-containing phospholipids in the inner and outer mitochondrial membranes of yeast committed to liponecrosis compromises mitochondrial functionality because it deteriorates such vital mitochondrial processes as respiration, electrochemical membrane potential and ATP synthesis [34, 35]. These dysfunctional mitochondria are unable to generate ATP in quantities that are sufficient for the energy-demanding process of assimilating exogenously added POA into triacylglycerols (TAG); TAG are neutral lipids initially synthesized in the ER and then deposited in lipid droplets (LD) [34, 35]. The synthesis and deposition of POA-containing TAG are considered pro-survival processes because they allow a reduction in the incorporation of POA into phospholipids, thus lowering their accumulation in the membranes of the ER, mitochondria and PM (Figure 1) [34, 49-52]. The dysfunctional mitochondria that are formed in yeast cells committed to liponecrosis can be selectively eliminated in the process of mitophagy. This autophagic degradation of dysfunctional mitochondria operates as a pro-survival process [34, 35], probably because of its well-known essential role in sustaining a population of functional mitochondria in a yeast cell (Figure 1) [53-55].

The accumulation of POA-containing phospholipids in both mitochondrial membranes can commit yeast to liponecrotic PCD not only because it weakens mitochondrial respiration, membrane potential and ATP synthesis but also because it considerably enhances the formation of reactive oxygen species (ROS) in mitochondria [34]. Due to such formation of mitochondrial ROS in bulk quantities, the cellular concentrations of ROS outside mitochondria in yeast committed to liponecrosis can exceed a cytotoxic threshold. This not only considerably reduces functionalities of various organelles by oxidatively damaging their protein and lipid constituents but also compromises cellular proteostasis by oxidatively damaging protein molecules confined to the cytosol (Figure 1) [34]. The numerous oxidatively damaged and dysfunctional organelles accumulated in yeast committed to liponecrosis undergo massive degradation. This pro-death process is executed by the cytosolic serine/threonine protein kinase Atg1 and several other proteins known to govern a non-selective autophagic breakdown of various organelles (Figure 1) $[34,35,56,57]$. The oxidatively damaged, dysfunctional, unfolded and aggregated cytosolic proteins that amass in yeast committed to liponecrosis are degraded in a prosurvival process executed by the metacaspase Ycal and serine protease Nma111 (Figure 1) [34]. Of note, Yca1 and Nma111 are known to be the key components of the caspase-dependent apoptotic pathway for breakdown of cytosolic proteins in yeast undergoing an apoptotic mode of PCD [58-60].

The accumulation of POA-containing phospholipids in the PM of yeast committed to liponecrosis leads to a re-distribution of phosphatidylethanolamine (PE) from the extracellular (outer) leaflet to the intracellular (inner) leaflet of the PM. The resulting depletion of PE in the outer leaflet of the PM is a pro-death process because it substantially increases the permeability of the PM for PI and other small molecules (Figure 1) [25, 34]. Such re-distribution of $\mathrm{PE}$ within the $\mathrm{PM}$ bilayer is driven by the alkaline-pH- and lipid-asymmetry-responsive Rim101 signaling pathway, which can be activated in response to the buildup of POA-containing phospholipids in this membrane bilayer [34]. Noteworthy, the Rim101 signaling pathway has been shown not only to accelerate the movement of PE from the outer leaflet of the PM to its inner leaflet but also to decelerate the movement of this phospholipid across the PM bilayer in the opposite direction [61-63].

It needs to be emphasized that at least two cellular processes can decelerate liponecrotic PCD because they both prevent a portion of exogenously added POA from being used for the synthesis of POA-containing phospholipids. As previously mentioned, one of these pro-survival cellular processes is POA incorporation into TAG and the ensuing deposition of these neutral lipids in LD (Figure 1) [34, 35]. Another such pro-survival cellular process is POA oxidation in peroxisomes of yeast cells exposed to this monounsaturated fatty acid (Figure 1) [34, 35]; peroxisomes are known for the essential role they play in oxidative degradation of fatty acids [64, 65].

\section{AEROBIC GLYCOLYSIS AND LIPOGENESIS: SIMILAR METABOLIC FEATURES OF THE FERMENTING YEAST $S$. CEREVISIAE AND CANCER CELLS}

A body of evidence implies that rapidly proliferating cells of the yeast $S$. cerevisiae grown in nutrient- and 
glucose-rich media exhibit some metabolic features that are similar to the key tumorigenic metabolic traits of different types of cancer cells [15, 17, 19, 20, 32, 66-68].

One of these similar metabolic traits is aerobic glycolysis, also known as the Warburg effect. This trait consists in the ability of cancer cells to metabolically convert glucose to lactate under aerobic conditions [18, 20, 69-71]. In all cancer cell types, this ability is known to be caused by enhanced glucose uptake and glycolysis, and in many types of cancer cells, such ability is also due to "the Crabtree effect" of suppressing mitochondrial respiration and oxidative phosphorylation [72-76]. It should be stressed that the conversion of glucose to lactate taking place in cancer cells under aerobic conditions is substantially less efficient in terms of ATP production per molecule of glucose than the one observed in noncancerous cells under the same conditions $[12,20,72,77$, $78]$. In the presence of oxygen, these non-cancerous cells

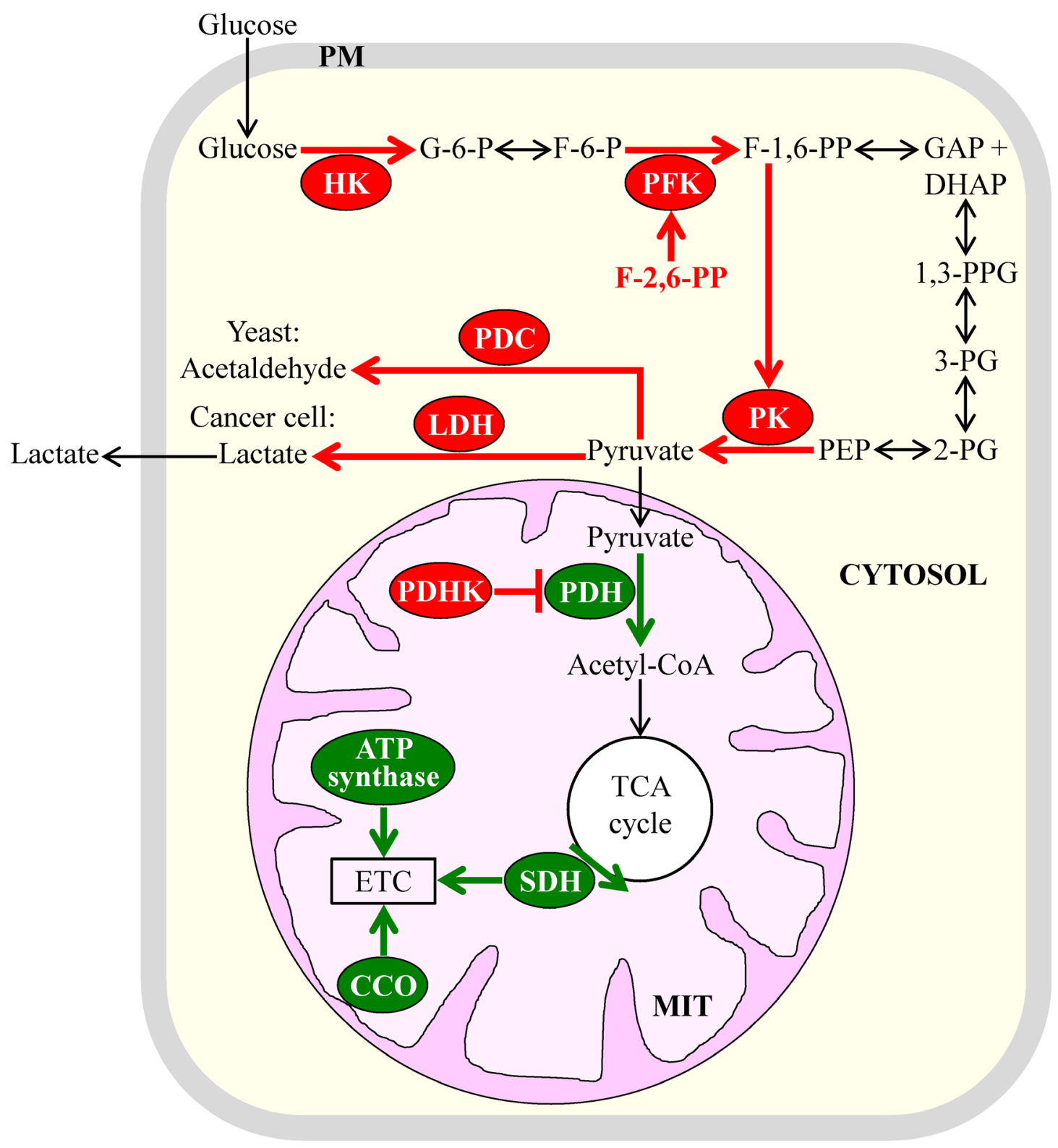

Figure 2: Some of the key metabolic processes underlying aerobic glycolysis in the fermenting yeast $S$. cerevisiae and cancer cells have similar rates and patterns of regulation in these two cell types. Because of these similarities, aerobic glycolysis is a common metabolic feature of rapidly proliferating yeast and cancer cells. Enzymes, metabolites and processes whose activities, concentrations and rates are increased or decreased are displayed in red or green color, respectively. See text for more details. Abbreviations: CCO, cytochrome $c$ oxidase; ETC, electron transport chain; HK, hexokinase; PDC, pyruvate decarboxylase; PDH, pyruvate dehydrogenase; PDHK, pyruvate dehydrogenase kinase; PFK, phosphofructokinase; PK, pyruvate kinase; PM, plasma membrane; LDH, lactate dehydrogenase; MIT, mitochondrion; SDH, succinate dehydrogenase; TCA, tricarboxylic acid. 
use the glycolytic metabolic pathway to convert glucose to pyruvate, which is then metabolized to carbon dioxide via oxidative phosphorylation in mitochondria [79-83]. Several metabolic processes are known to underlie the phenomenon of aerobic glycolysis. It seems that aerobic glycolysis is common to the fermenting yeast $S$. cerevisiae and different types of cancer cells because many of these metabolic processes have similar relative rates, exhibit similar regulation patterns, and are catalyzed by enzymes sharing significant sequence homologies in yeast and cancer cells [15, 18, 66-68, 72, 77, 83]. Such similarities between the key metabolic processes underlying aerobic glycolysis in rapidly proliferating yeast and cancer cells are outlined schematically in Figure 2 and include the following: (1) elevated cytosolic levels of hexokinase isoforms that have high affinities for glucose and low sensitivities to feedback inhibition by glucose-6phosphate $[11,13,14,84,85]$; (2) increased enzymatic activities of cytosolic phosphofructokinase and augmented concentrations of fructose-2,6-bisphosphate, a potent allosteric activator of phosphofructokinase [15, 18, 66, 82, 86]; (3) raised levels of cytosolic pyruvate kinase isoforms highly sensitive to allosteric activation by fructose-1,6bisphosphate, a product of the reaction catalyzed by phosphofructokinase [82, 87-92]; (4) elevated cytosolic levels and enzymatic activities of pyruvate decarboxylase

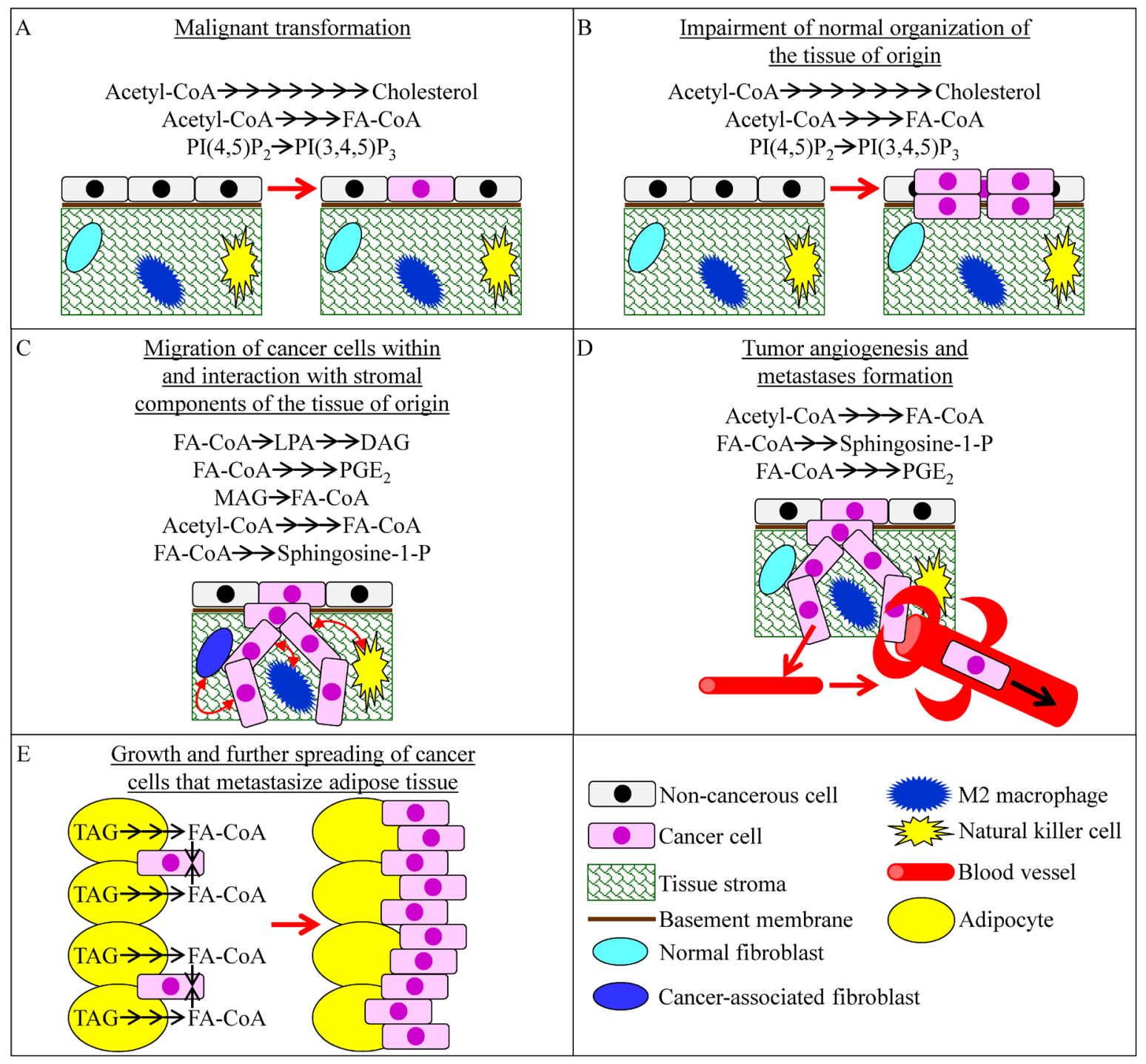

Figure 3: Some changes affecting lipid metabolism in cancer cells can play causal roles in certain aspects of cancer initiation, promotion and progression. These aspects include malignant transformation of cells A., tumorigenic impairment of normal organization of the tissue of origin B., migration of cancer cells within the tissue of origin and interaction with stromal components of this tissue C., tumor angiogenesis and the ensuing formation of metastases D., and growth and further spreading of the cancer cells metastasizing adipose tissue E.. See text for more details. Abbreviations: DAG, diacylglycerol; FA-CoA, acyl-CoA ester of fatty acid; LPA, lysophosphatidic acid; MAG, monoacylglycerol; $\mathrm{PGE}_{2}$, prostaglandin E2; PI (4, 5) $\mathrm{P}_{2}$, phosphatidylinositol-4, 5-bisphosphate; PI (3, 4, 5) $\mathrm{P}_{3}$, phosphatidylinositol-3, 4, 5-triphosphate. 
in yeast and lactate dehydrogenase in cancer cells, both of which lower mitochondrial oxidation of pyruvate by catalyzing its conversion into cytosolic acetaldehyde or cytosolic lactate, respectively [66, 82, 93-96]; (5) increased levels of mitochondrial pyruvate dehydrogenase kinase, which causes a decrease in mitochondrial pyruvate oxidation by phosphorylating and inhibiting pyruvate dehydrogenase in mitochondria [66, 97-101]; and (6) reduced levels and/or activities of such vital components of the mitochondrial ETC as succinate dehydrogenase (complex II; it is also an enzyme of the mitochondrial TCA cycle), cytochrome $c$ oxidase (complex IV) and ATP synthase (complex V) [102-108]. Of note, although most known types of cancer cells permanently exhibit the Warburg effect of enhanced glucose uptake and intensified glycolysis, some of these cancer cell types display the Crabtree effect of suppressed mitochondrial TCA cycle, ETC and/or ATP synthesis only temporally whereas others never exhibit such an effect [15, 66, 109-113].
Fermenting cells of the yeast $S$. cerevisiae have another characteristic metabolic feature which is known as one of the key tumorigenic metabolic traits of cancer cells. This metabolic feature is called lipogenesis. It is common to rapidly proliferating yeast and cancer cells because both cell types require abundant quantities of membrane lipids that can be used for (1) cell growth and mitotic division, and (2) membrane trafficking and membrane-associated signaling $[7,11,14,16,19,20,77,80,114-121]$. Lipogenesis refers to a type of metabolic reprogramming in which the surplus metabolites produced by aerobic glycolysis can be used for the de novo synthesis of bulk quantities of membrane lipids, mainly (but not exclusively) fatty acids, phospholipids and cholesterol [1, 18, 20, 77, $114,119]$. Recent evidence indicates that certain features of such reprogramming of lipid metabolism in cancer cells may play causal roles in malignant transformation and tumor development. The features of reprogrammed lipid metabolism that can affect some specific aspects of cancer

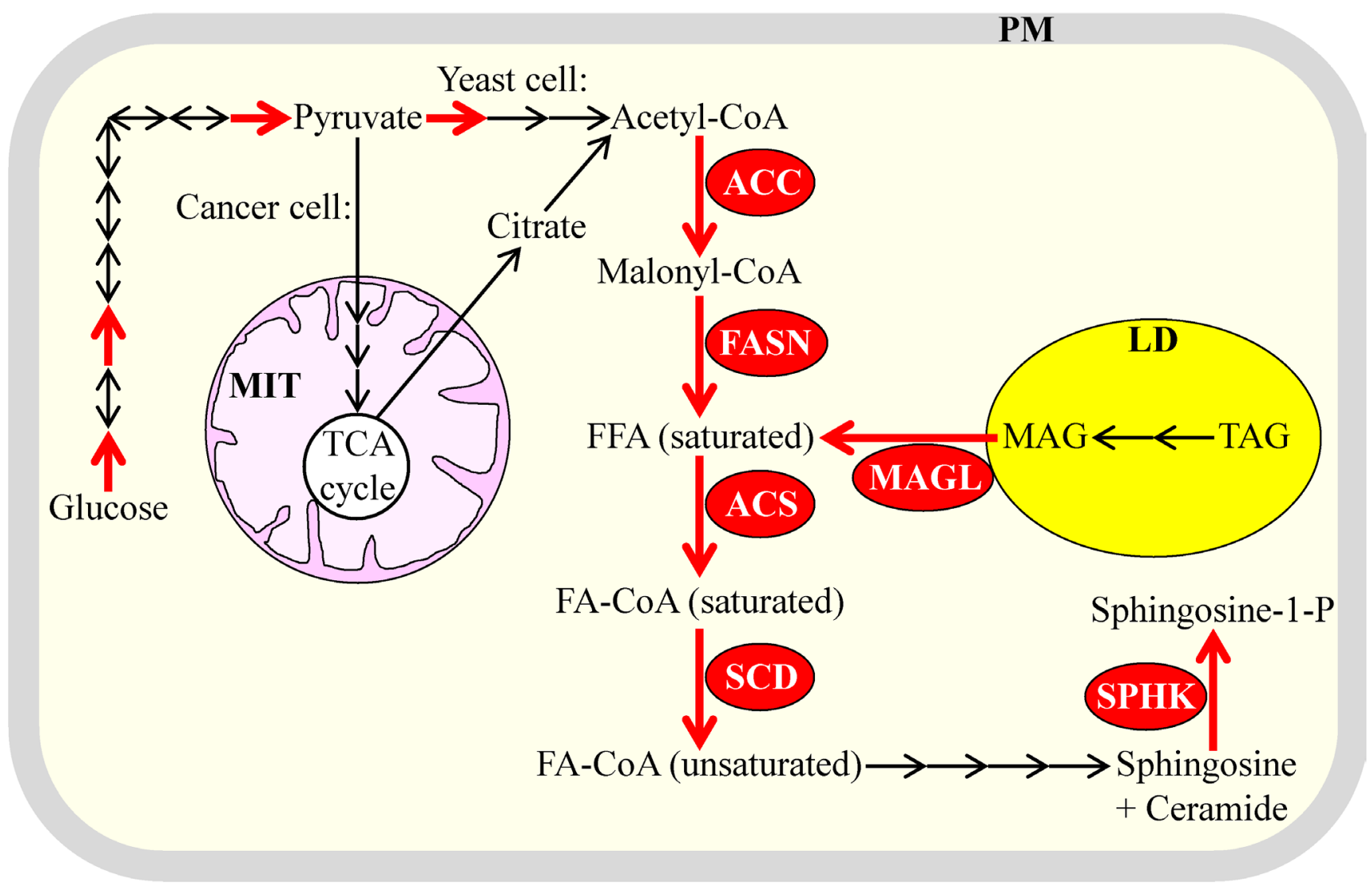

Figure 4: Several of the key metabolic processes underlying lipogenesis in the fermenting yeast $S$. cerevisiae and cancer cells have comparable rates and exhibit analogous patterns of regulation in these two cell types. Due to such similar properties of the key metabolic processes that underlie lipogenesis, it is a common metabolic trait of the rapidly proliferating yeast and cancer cells. Enzymes and processes exhibiting increased activities and rates are displayed in red color. Glycolytic processes whose rates are elevated in yeast and cancer cells are also shown in red color; enzymes catalyzing these processes are named in Figure 2. See text for more details. Abbreviations: ACC, acetyl-CoA carboxylase; ACS, acyl-CoA synthetase; FA-CoA, acyl-CoA ester of fatty acid; FASN, fatty acid synthase; FFA, free fatty acid; LD, lipid droplets; MAG, monoacylglycerol; MAGL, monoacylglycerol lipase; MIT, mitochondria; PM, plasma membrane; SCD, stearoyl-CoA desaturase; SPHK, sphingosine-1-kinase; TAG, triacylglycerol; TCA, tricarboxylic acid. 
initiation, promotion and progression are recapitulated schematically in Figure 3 and include the following: (1) a stimulation of the mevalonate pathway of cholesterol synthesis, activation of fatty acid synthesis and induction of phosphatidylinositol-3,4,5-triphosphate synthesis which can all promote malignant transformation of cells and can also contribute to the tumorigenic impairment of normal tissue organization (Figure 3A and 3B) [7, 120, 122-130]; (2) a lipogenic incorporation of fatty acids into diacylglycerol, lysophosphatidic acid and prostaglandin $\mathrm{E}_{2}$, as well as a lipolytic, monoacylglycerol lipase (MAGL)-driven formation of fatty acids from monoacylglycerols, all of which can help cancer cells to invade the tissue of origin by stimulating the migration of cancer cells within this tissue and also by promoting the interaction of cancer cells with stromal components of this tissue (Figure 3C) [6, 125, 131-137]; (3) the de novo synthesis of fatty acids from acetyl-CoA and the formation of lysophosphatidic acid, sphingosine-1-phosphate and prostaglandin $\mathrm{E}_{2}$ from fatty acids which can support cancer cell invasion within the tissue of origin by guiding the bidirectional communications between the invading cancer cells and such stromal components as cancer-associated fibroblasts, M2 macrophages and natural killer cells (Figure 3C) [125, 138-141]; (4) the de novo synthesis of fatty acids, sphingosine-1-phosphate and prostaglandin $E_{2}$ which can accelerate tumor angiogenesis, thus facilitating the spreading of cancer cells into other tissues and supporting the formation of metastases (Figure 3D) [125, 142-148]; and (5) the lipolysis of TAG deposited in LD within adipocytes adjacent to cancer cells that metastasize adipose tissue which allows cancer cells to generate bulk quantities of fatty acids; after being transferred to metastatic cancer cells, these fatty acids can be oxidized in mitochondria to support the growth and further spreading of the cancer cells (Figure 3E) [149-152].

Akin to aerobic glycolysis, lipogenesis is common to the fermenting yeast $S$. cerevisiae and cancer cells because several key processes underlying this metabolic trait exhibit comparable rates, display analogous patterns of regulation and are driven by orthologous proteins in yeast and cancer cells $[1,16,19,50,51,81,114,119,120$, $153,154]$. Such similar properties of the key metabolic processes underlying lipogenesis in rapidly proliferating yeast and cancer cells are displayed schematically in Figure 4 and include the following: (1) increased activities

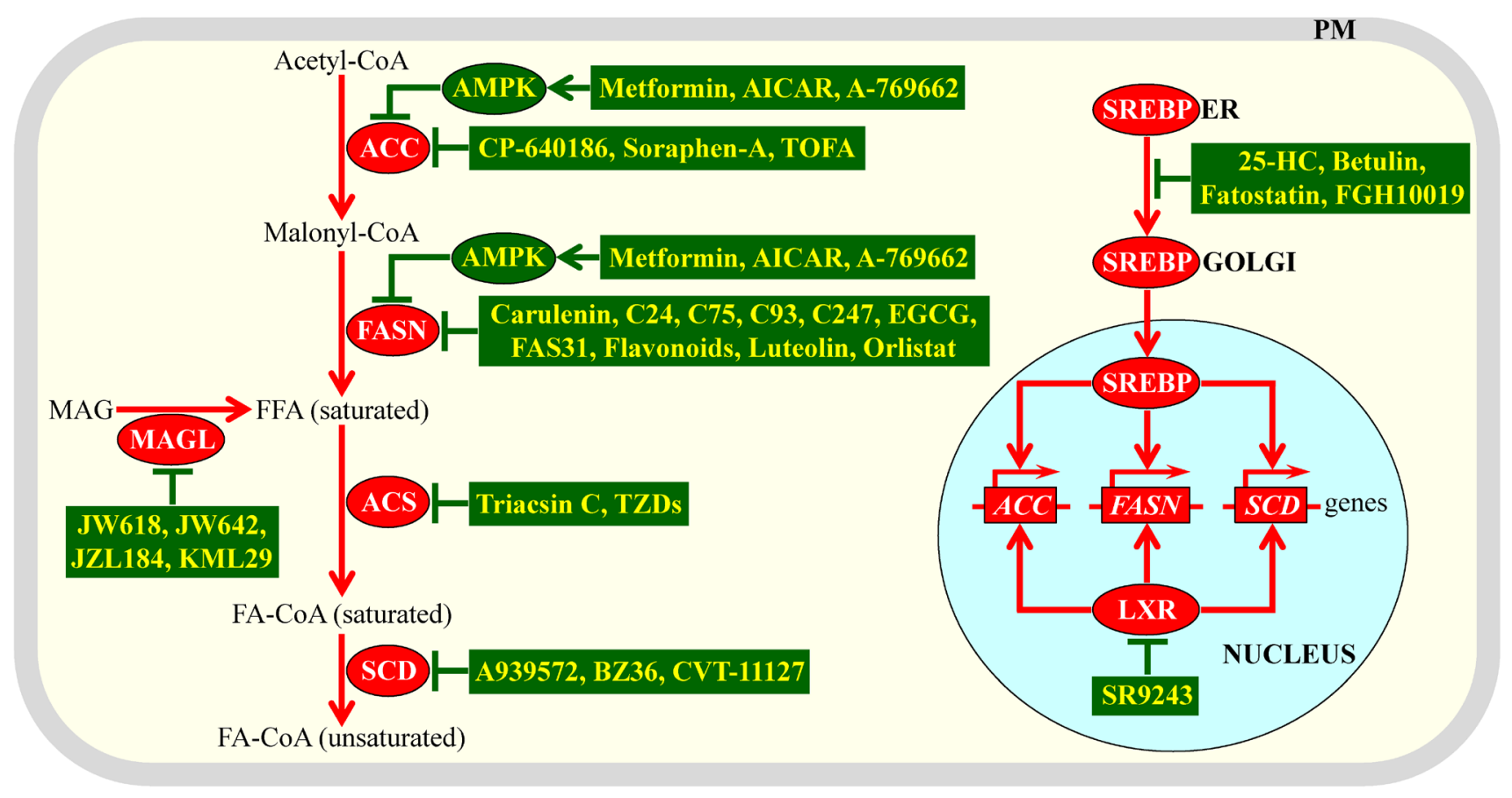

Figure 5: Different mechanisms by which various anti-tumor pharmaceuticals can inhibit lipogenesis in cancer cells. These mechanisms decelerate lipogenesis-related processes common to rapidly proliferating yeast and cancer cells. Genes, proteins and processes whose increased expression levels, activities and rates promote tumorigenesis in cells that are not exposed to lipogenesisinhibiting small molecules are displayed in red color. Proteins and processes whose activities and rates attenuate tumorigenesis in response to cell treatment with lipogenesis-inhibiting small molecules are displayed in green color. See text for more details. Abbreviations: 25HC, 25-hydroxycholesterol; ACC, acetyl-CoA carboxylase; ACS, acyl-CoA synthetase; AICAR, 5-aminoimidazole-4-carboxamide ribonucleoside; AMPK, AMP-activated protein kinase; EGCG, epigallocatechin-3-gallate; ER, endoplasmic reticulum; FA-CoA, acylCoA ester of fatty acid; FASN, fatty acid synthase; FFA, free fatty acid; LXR, liver-X-receptor; MAG, monoacylglycerol; MAGL, monoacylglycerol lipase; PM, plasma membrane; SCD, stearoyl-CoA desaturase; SREBP, sterol regulatory element-binding protein; TOFA, 5-(tetradecyloxy)-2-furoic acid; TZDs, thiazolidinediones. 
of the enzymes involved in the de novo synthesis of acylCoA esters of saturated fatty acids from acetyl-CoA; among these enzymes are acetyl-CoA carboxylase (ACC), fatty acid synthase (FASN) and acyl-CoA synthetase (ACS) in cancer cells and their orthologues Acc1, Fas1/ Fas 2 complex and Faa1 in yeast [1, 19, 155-160]; (2) an elevated enzymatic activity of stearoyl-CoA desaturase (SCD; this enzyme catalyzes the desaturation of stearoylCoA to oleoyl-CoA) in cancer cells and of the orthologous enzyme Ole1 in yeast [1, 5, 16, 19, 161-163]; (3) an amplified enzymatic activity of sphingosine-1-kinase (which accelerates the formation of the potent signaling molecule sphingosine-1-phosphate from acyl-CoA esters of fatty acids) in cancer cells and of its orthologues Lcb4 and Lcb5 in yeast [16, 19, 143, 164-167]; and (4) an elevated enzymatic activity of MAGL (which catalyzes the lipolytic formation of fatty acids from monoacylglycerols) in cancer cells; in rapidly proliferating yeast, the TAG lipase Tgl4 is likely to play a similar role in providing fatty acids to support cell growth, division, membrane trafficking and membrane-associated signaling $[6,19,115$, $117,133,137]$. Noteworthy, although many types of solid tumors exhibit both aerobic glycolysis and lipogenesis, primary prostate cancers display only lipogenesis as a characteristic metabolic trait $[10,158,168-171]$.

\section{A CURRENT APPROACH TO DEVELOPING SELECTIVE ANTI- TUMOR PHARMACEUTICALS THAT CAN REORGANIZE LIPID METABOLISM: SEARCHING FOR INHIBITORS OF LIPOGENESIS}

The current strategy for discovering anti-tumor pharmaceuticals that target lipid metabolism consists of searching for small molecules capable of inhibiting lipogenesis in cancer cells. Such molecules are expected to diminish the quantities of membrane lipids available to support proliferation and survival of cancer cells without impairing functionality and viability of noncancerous cells. This strategy for uncovering anti-tumor therapeutic agents has recently been extensively exploited in a number of studies, and their major findings have been reviewed elsewhere $[1-3,6,10,19,81,82,119,133$, $148,155,158,170,172-177]$. Figure 5 schematically summarizes four different mechanisms through which various pharmacological interventions can inhibit lipogenesis in cancer cells by slowing down lipogenesisrelated processes that are also known to support rapid proliferation of fermenting yeast. These mechanisms include the following: (1) a direct chemical inhibition of ACC, FASN, ACS, SCD or MAGL by a distinct set of small molecules, each of which can specifically bind to one of these enzymes (Figure 5) [1, 6, 10, 133, 155, 160, 178-191]; (2) a metformin-, 5-aminoimidazole-4- carboxamide ribonucleoside (AICAR)- or A-769662dependent activation of AMP-activated protein kinase (AMPK), which then phosphorylates and inhibits ACC and FASN (Figure 5) [1, 10, 19, 192-197]; (3) an interaction of the small molecule SR9243 with the nuclear liver-X-receptor (LXR); such interaction attenuates the LXR-driven transcription of nuclear genes encoding ACC, FSN and SCD (Figure 5) [2, 198]; and (4) an inhibition of the ER-to-Golgi transport of sterol regulatory elementbinding proteins (SREBP) by betulin and several other small molecules; such inhibition impairs the proteolytic processing of SREBP in the Golgi, thus preventing the import of active fragments of SREBP into the nucleus and attenuating SREBP-dependent transcription of nuclear genes encoding ACC, FSN and SCD (Figure 5) [1, 199201].

\section{A NOVEL APPROACH TO DISCOVERING SELECTIVE ANTI-TUMOR PHARMACEUTICALS THAT CAN ALTER LIPID METABOLISM: THE SEARCH FOR ACTIVATORS OF LIPONECROSIS}

A growing body of evidence indicates that the proliferation of cancer cells can be decelerated and their survival can be compromised by genetic and pharmacological interventions capable of altering (i.e. decreasing or increasing) "the fatty acid desaturation index". The index is defined as the ratio of monounsaturated fatty acids (MUFA) to saturated fatty acids (SFA) [202, 203]. The value of this index in human cells depends mainly on the enzymatic activity of the SCD1 isoform of stearoyl-CoA desaturase. This ERassociated acyl-CoA delta-9 desaturase accelerates the introduction of a cis-double bond between carbons 9 and 10 of acyl-CoA esters of palmitic or stearic acid to produce acyl-CoA esters of palmitoleic or oleic acid, respectively [204-207]. Palmitic and stearic acid are the most abundant SFA in cancer cells, whereas palmitoleic and oleic acid are the major MUFA [5, 208-211]. All four of these fatty acids are the predominant forms of cellular lipids that can be found as free SFA or MUFA and their acyl-CoA esters. The bulk of these fatty acids (especially MUFA) in cancer cells can also be incorporated into membrane phospholipids, neutral lipids and sphingolipids $[114,158$, 208-211].

Inhibition of SCD1 activity, either by certain genetic manipulations or by some pharmaceuticals (see Figure 5), decreases the fatty acid desaturation index. Such inhibition has been shown to exhibit potent anti-tumor effects in different forms of cancer by affecting various aspects of cancer initiation, promotion and progression [5, 163, 180, 184, 186, 188, 212-219]. Recent studies have suggested two different types of mechanisms through which such inhibition of SCD1 and the resulting 
decrease of the fatty acid desaturation index (i.e. a rise of cellular SFA concentration and a concomitant decline of cellular MUFA concentration) can cause the observed anti-tumor effects. These two types of mechanisms are recapitulated schematically in Figure 6. They include the following: (1) the build-up of SFA alters the structure of the ER membrane and impairs its functionality, thereby eliciting the unfolded protein response signaling pathway in the ER and excessively stressing this organelle [162, 220-229]; if such SFA-driven stress in the ER exceeds a cytotoxic threshold in cancer cells with inhibited SCD1, these cells undergo apoptosis [215, 219]; and (2) SCD1 inhibition in cancer cells substantially decelerates the flow of the surplus glycolytic metabolites into fatty acid synthesis (and thus, suppresses lipogenesis) by eliciting a significant decrease in the enzymatic activity of ACC; this suppressing effect of SCD1 inhibition on lipogenesis is due to the following demonstrated abilities of such inhibition: (a) it activates AMPK, which then phosphorylates and inhibits ACC, (b) it elevates cellular concentrations of saturated acyl-CoA species known to inhibit ACC allosterically, and (c) it attenuates the phosphatidylinositol-3 kinase/Akt signaling pathway needed for SREBP-driven transcription of nuclear genes encoding ACC and other lipogenic enzymes [5, 80, 163, $180,188,214,230-233]$.

Noteworthy, various cell lines of breast, colorectal and prostate cancers have been shown to possess

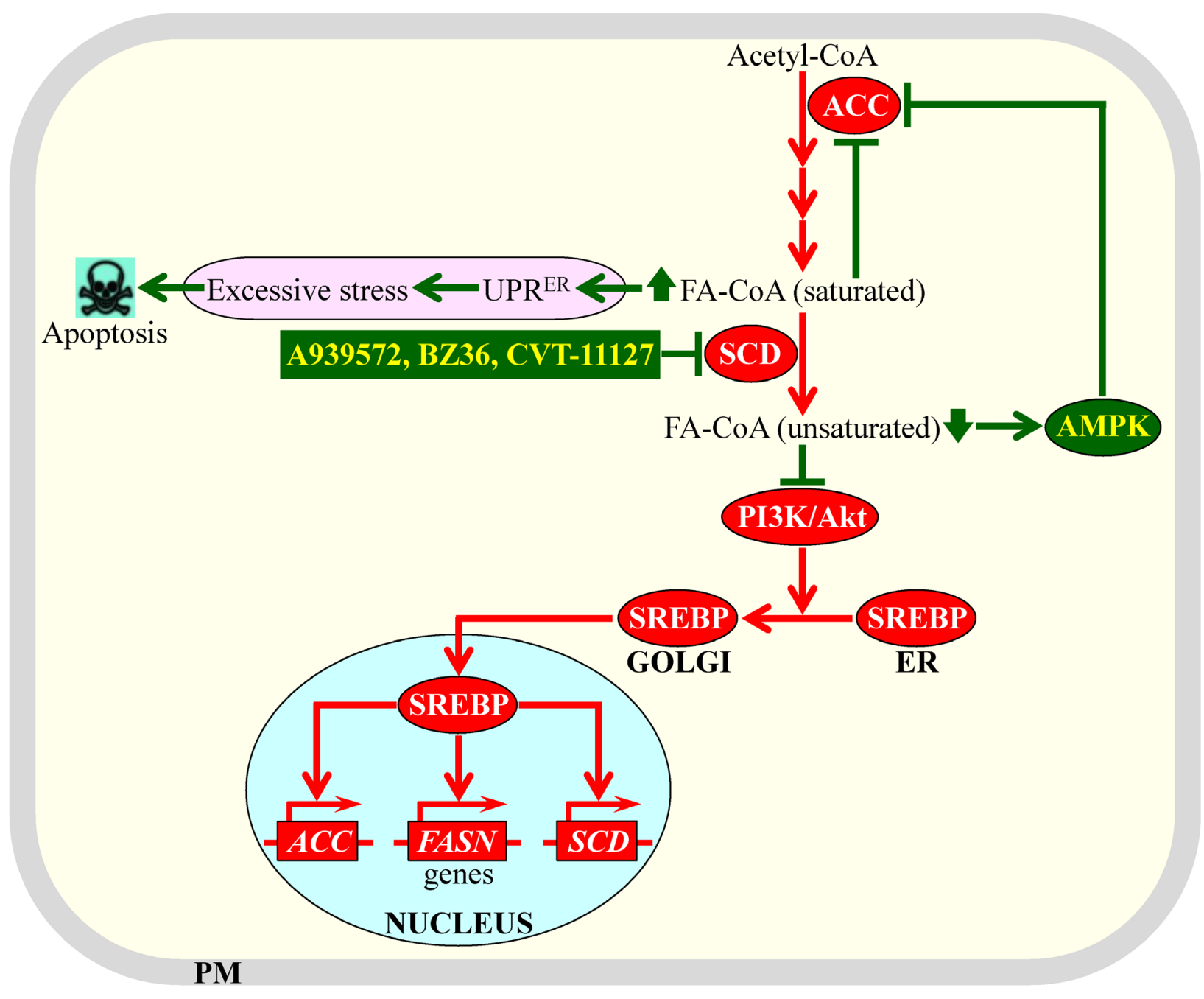

Figure 6: Mechanisms through which an inhibition of stearoyl-CoA desaturase (SCD) by some pharmaceuticals can cause potent anti-tumor effects. Such inhibition elicits a rise of cellular concentrations of acyl-CoA esters of saturated fatty acids and a concomitant decline of cellular concentrations of acyl-CoA esters of unsaturated fatty acids. Genes, proteins and processes whose increased expression levels, activities and rates promote tumorigenesis in cells that are not exposed to the SCD inhibitors are displayed in red color. Proteins and processes whose activities and rates attenuate tumorigenesis in response to cell treatment with the SCD inhibitors are displayed in green color. See text for more details. Abbreviations: ACC, acetyl-CoA carboxylase; AMPK, AMP-activated protein kinase; Akt, a serine/threonine-specific protein kinase; ER, endoplasmic reticulum; FA-CoA, acyl-CoA ester of fatty acid; FASN, fatty acid synthase; PI3K/Akt, phosphatidylinositol-3 kinase/Akt signaling pathway; PM, plasma membrane; SREBP, sterol regulatory elementbinding protein; $\mathrm{UPR}^{\mathrm{ER}}$, the unfolded protein response signaling pathway in the ER. 
substantially increased lipogenic activities [217]. Moreover, in primary prostate cancers, lipogenesis (but not aerobic glycolysis) is known to be the only prominent tumorigenic trait of metabolism [10, 158, 168-171]. It needs to be emphasized that cells of all these highly lipogenic cancer forms have been shown to exhibit a considerably reduced fatty acid desaturation index (i.e. the concentrations of MUFA in these cells are decreased whereas cellular concentrations of SFA are increased) if the cells are not exposed to an anti-tumor agent [217]. However, these highly lipogenic cancer cells display a substantially elevated fatty acid desaturation index (i.e. the concentrations of both SFA and MUFA in these cells are decreased whereas cellular concentrations of polyunsaturated (PUFA) fatty acids are substantially increased) if the cells are subjected to genetic or pharmaceutical interventions lowering lipogenesis and causing robust anti-tumor effects [217]. Because the highly lipogenic cells of breast, colorectal and prostate cancers exposed to such anti-tumor interventions exhibited an elevated fatty acid desaturation index and increased concentrations of peroxidation-susceptible PUFA, these cells displayed raised concentrations of oxidatively damaged membrane lipids, enhanced susceptibility to oxidative stress, declined protein mobility within lipid membrane bilayers and augmented permeability of the PM bilayer to small molecules [217]. It is conceivable therefore that some small molecules capable of increasing the fatty acid desaturation index in the highly lipogenic cancer cells (for instance, by stimulating SCD1 activity) may exhibit robust anti-tumor effects in these rapidly proliferating cells. Because lipogenesis is a common metabolic trait of cancer cells and rapidly proliferating fermenting yeast (see above), it is likely that such antitumor small molecules may also cause rapid loss of cell viability in yeast.

Furthermore, it has been demonstrated that cancer cells constitutively overexpressing Ole1, a yeast ortholog of human SCD1, exhibit an increased fatty acid desaturation index due to the elevated concentrations of

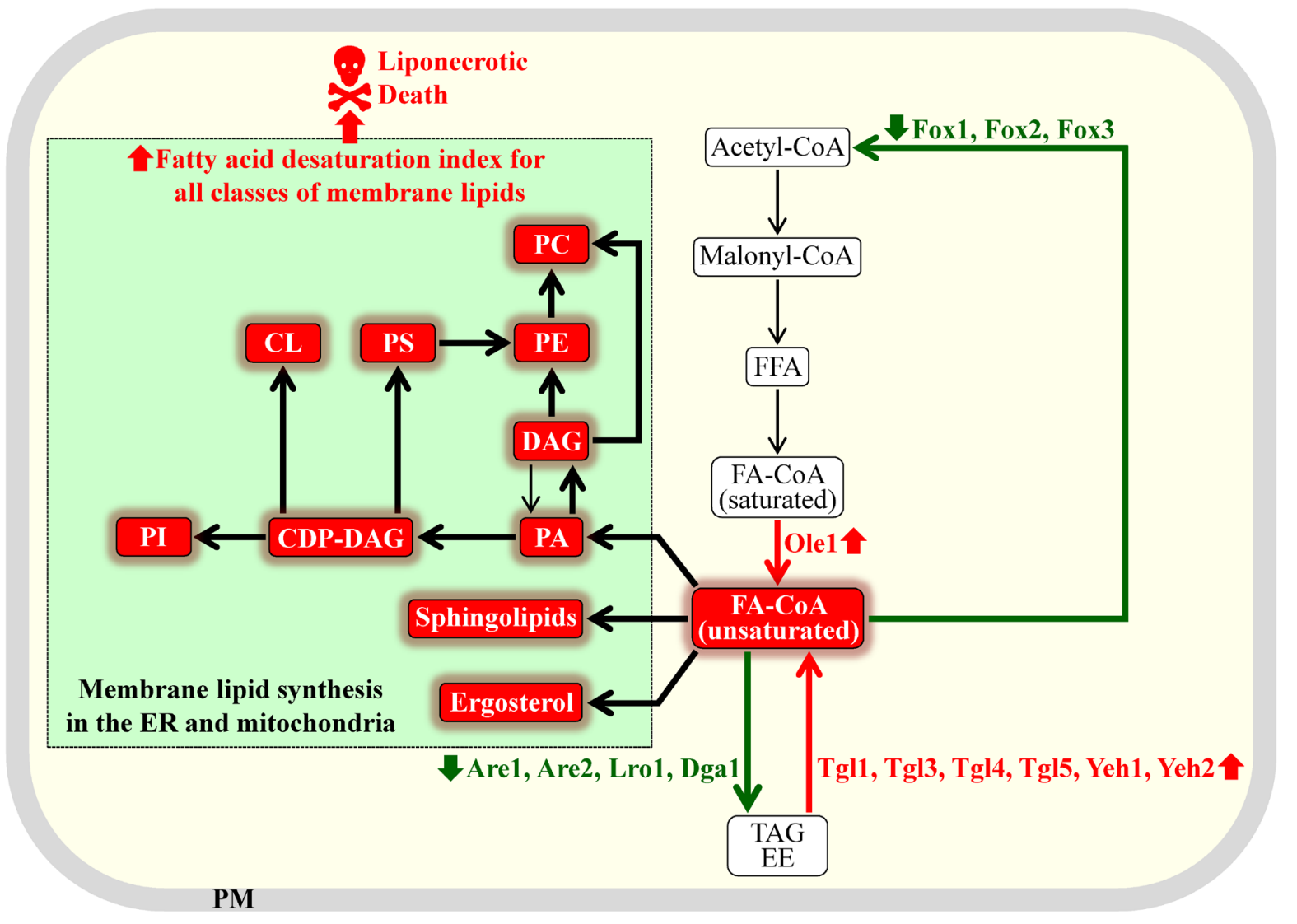

Figure 7: Different ways of increasing the fatty acid desaturation index of various membrane lipids in yeast with the help of small molecules. A small molecule eliciting any of these methods for increasing the fatty acid desaturation index can commit rapidly proliferating fermenting yeast to liponecrotic programmed cell death. Proteins and processes whose elevated or lowered activities and rates can increase the fatty acid desaturation index of membrane lipids are displayed in red or green color, respectively. Thick black arrows indicate processes whose rates are expected to be intensified in yeast exposed to a small molecule capable of increasing the fatty acid desaturation indexes of various membrane lipids. See text for more details. Abbreviations: CDP-DAG, cytidine diphosphate diacylglycerol; CL, cardiolipin; DAG, diacylglycerol; EE, ergosteryl ester; ER, endoplasmic reticulum; FA-CoA, acyl-CoA ester of fatty acid; FFA, free fatty acid; PA, phosphatidic acid; PC, phosphatidylcholine; PE, phosphatidylethanolamine; PI, phosphatidylinositol; PM, plasma membrane; PS, phosphatidylserine; TAG, triacylglycerol. 
MUFA in these cells [234, 235]. It should be stressed that such a rise in the fatty acid desaturation index not only enhances the fluidity of membrane bilayers in these cancer cells but also considerably increases cell susceptibility to exogenous tumor necrosis factor $[234,235]$. Of note, an elevated level of Ole1 expression has been shown to impair growth and division of fermenting yeast [236]. Thus, again, it seems that pharmaceuticals capable of increasing the fatty acid desaturation index in rapidly proliferating cancer cells by elevating SCD activity may have high anti-tumor potential. It is feasible that these anti-tumor pharmaceuticals may also compromise survival of rapidly proliferating yeast.

Moreover, a yeast mutant concurrently lacking acyltransferases Lro1, Dga1, Are1 and Are2 is known to be unable to incorporate acyl-CoA esters of MUFA into TAG [237]. It has been shown that cells of this mutant exhibit excessive proliferation of ER membranes and rapidly die only if exposed to exogenous MUFA [237]. In contrast, an exposure of these mutant cells to SFA does not cause ER membrane proliferation or loss of cell viability [237]. It is therefore likely that some small molecules capable of reducing the incorporation of MUFA into TAG may kill fermenting yeast cells. Due to similarities of lipogenic processes taking place in these rapidly proliferating cells and in cancer cells (see above), it is conceivable that such small molecules may also exhibit robust anti-tumor effects.

Based on the above findings, we propose the following approach to using fermenting yeast as a model organism for the discovery of anti-tumor pharmaceuticals that can alter lipid metabolism. As discussed above, small molecules that can increase the fatty acid desaturation index of free fatty acids, phospholipids, ergosterol and sphingolipids in fermenting yeast cells may not only cause death of these cells but may also selectively kill rapidly proliferating cancer cells. There are at least four different ways of increasing the fatty acid desaturation index of various lipid classes in yeast with the help of small molecules. These ways are outlined schematically in Figure 7 and include the following: (1) elevating the enzymatic activity of the delta-9 fatty acid desaturase Ole1, which catalyzes the formation of acyl-CoA esters of unsaturated fatty acids from acyl-CoA esters of saturated fatty acids $[16,50,51] ;$ (2) raising the enzymatic activities of lipases involved in the hydrolytic formation of acylCoA esters of unsaturated fatty acids from TAG and ergosteryl esters (EE); these lipases include Tgl1, Tgl3, Tg14, Tg15, Yeh1 and Yeh2 [16, 50, 51]; (3) decreasing the enzymatic activities of acyltransferases that accelerate the incorporation of acyl-CoA esters of unsaturated fatty acids into TAG and EE; among these acyltransferases are Dgal, Lro1, Are1 and Are2 [16, 50, 51]; and (4) decreasing the activities of peroxisomal enzymes Fox1, Fox2 and Fox3, all of which are involved in degradative $\beta$-oxidation of acyl-CoA esters of unsaturated fatty acids $[16,50,51]$. It needs to be emphasized that a small molecule eliciting any of these methods for increasing the fatty acid desaturation index of membrane lipids is expected to cause a buildup of unsaturated lipids in the membrane bilayers of ER, mitochondria and PM. As it has been mentioned in the first section of this review, the excessive accumulation of POA-containing lipids in the membrane bilayers of ER, mitochondria and PM can commit yeast to liponecrotic PCD; POA is a 16-carbon MUFA [25, 33-35]. It is therefore conceivable that pharmaceuticals causing an increase in the fatty acid desaturation index of membrane lipids can trigger liponecrotic cell death of fermenting yeast. As discussed above, due to the similarities of lipogenic processes taking place in rapidly proliferating fermenting yeast and in cancer cells, it is plausible that such pharmaceuticals may also have robust anti-tumor effects.

Of note, our recent studies have convincingly demonstrated the applicability of yeast as a model organism for the discovery of selective anti-tumor small molecules targeting a certain aspect of tumorigenesis. Specifically, our high-throughput chemical genetic screen for pharmaceuticals that can extend yeast longevity has identified lithocholic acid (LCA), the most hydrophobic bile acid, as one of them [25]. We have uncovered the molecular and cellular mechanisms through which LCA increases the lifespan of chronologically aging yeast $[33,45,55,238-241]$. It appears that LCA is not only a longevity-extending molecule in yeast but also a potent anti-tumor agent in human cells. Indeed, at concentrations that are not cytotoxic to non-cancerous cells, LCA can selectively kill cultured human breast, prostate and neuroblastoma cancer cells $[26,238,242]$. Of note, cancer is considered a disease of aging [7, 243-246]. This assertion is based on the following findings: (1) age in the major risk factor for developing cancer; (2) genetic, dietary and pharmacological interventions that delay aging in animal models reduce the incidence of cancer; and (3) some of the evolutionarily conserved pathways and mechanisms underlying cancer and aging are common to these two inherently complex biological phenomena [7, 243, 247-251].

We therefore propose here to use a high-throughput screen for small molecules that can activate liponecrotic PCD of fermenting yeast by increasing the fatty acid desaturation index of membrane lipids. This screen is depicted schematically in Figure 8. It is based on employing a microplate assay for measuring the viability of yeast cells via monitoring the optical density of a yeast culture at $600 \mathrm{~nm}\left(\mathrm{OD}_{600}\right)$. In the proposed screen, fast proliferating yeast cells cultured in a nutrient- and glucose-rich medium and progressing through the exponential growth phase are initially incubated for $2 \mathrm{~h}$ in master microplates. Yeast cultures in individual wells of these master microplates are supplemented with various small molecules from a compound library. Wells in one 
set of master microplates do not contain POA, whereas wells in another set of such microplates contain $50 \mu \mathrm{M}$ POA. At this concentration, exogenously added POA kills not more than $20 \%$ of the total number of cells in a yeast culture $[34,35]$. After $2 \mathrm{~h}$ of incubation in master microplates, a small aliquot of each culture is diluted 1:200 in an individual well of a replica microplate. Wells in all replica microplates contain only a growth medium rich in nutrients and glucose. After $16 \mathrm{~h}$ of incubation, the $\mathrm{OD}_{600}$ of a cell culture in each well of the replica microplates is measured. This incubation time is optimal for the value of $\mathrm{OD}_{600}$ to correlate with the number of viable cells in a well of the replica microplate (Figure 8) [25]. The small molecules from a compound library that cause the highest extent of decrease in the value of the $\mathrm{OD}_{600}$ of a cell culture are chosen as "lead" compounds. These compounds are then used for "cherry-picking" of "lead" compounds capable of activating liponecrotic PCD of yeast by increasing the fatty acid desaturation index of membrane lipids.

The high-throughput screen outlined in Figure 8 can be conducted using the following yeast strains: (1) a wild-type strain, which exhibits "normal" concentrations and activities of Ole1, Tgl1, Tgl3, Tgl4, Tg15, Yeh1, Yeh2, Dga1, Lro1, Are1 and Are2; as outlined above, activities of all these enzymes play essential roles in defining the intracellular concentrations of acyl-CoA esters of MUFA
(Figure 7); (2) a yeast strain constitutively overexpressing the delta-9 fatty acid desaturase Ole1, which catalyzes the formation of acyl-CoA esters of MUFA (Figure 7); as mentioned above, this mutant strain exhibits an increased fatty acid desaturation index of all membrane lipid classes because it accumulates MUFA at high concentrations [234, 235]; and (3) a yeast strain concurrently lacking acyltransferases Lro1, Dga1, Are1 and Are2; as outlined earlier in the text, this strain is unable to incorporate acyl-CoA esters of MUFA into TAG (Figure 7) and, thus, amasses MUFA-containing membrane lipids at high concentrations [237]. It is possible that the above highthroughput screen may reveal small molecules causing a substantial decrease in the $\mathrm{OD}_{600}$ of a cell culture not only for the yeast strain overexpressing Ole1, but also for the yeast strain concurrently lacking acyltransferases Lro1, Dga1, Are1 and Are2. Moreover, among such small molecules there may be those that do not decrease (or decrease only slightly) the $\mathrm{OD}_{600}$ of a cell culture for a wild-type strain of yeast. These small molecules are expected to exhibit a combination of the following two features: (1) they may cause rapid loss of cell viability only in yeast strain exhibiting increased concentrations of acyl-CoA esters of POA (and of other MUFA) and elevated concentrations of POA-containing (and of other MUFA-containing) membrane lipids; and (2) they may selectively kill only lipogenic cancer cells without
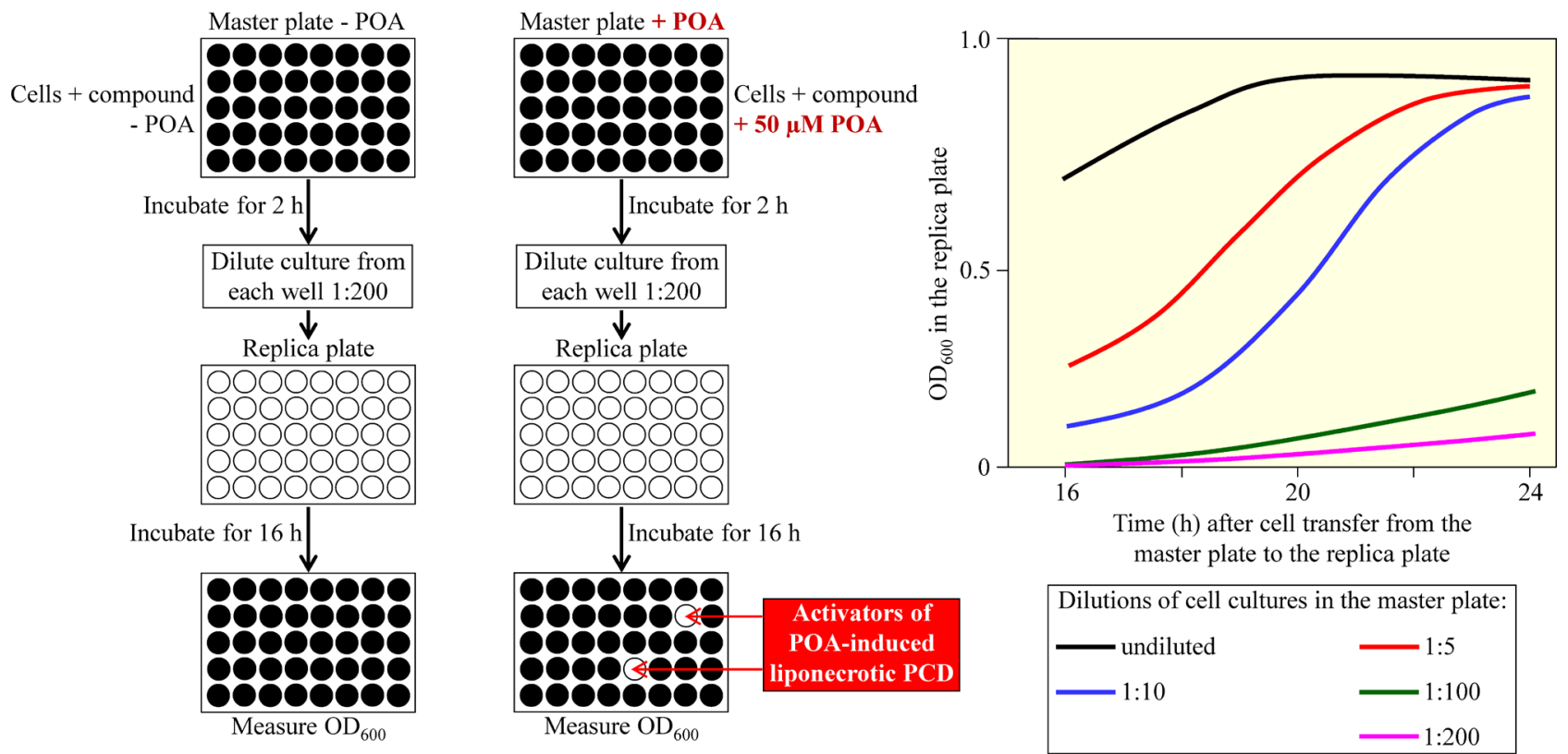

Figure 8: A microplate assay for measuring the viability of yeast cells by monitoring the optical density of a yeast culture at $600 \mathrm{~nm}\left(\mathrm{OD}_{600}\right)$. This high-throughput assay can be used to screen compound libraries for small molecules that activate palmitoleic acid (POA)-induced liponecrotic cell death of fermenting yeast. Fast growing yeast cells are first incubated for $2 \mathrm{~h}$ in master microplates containing growth medium and various small molecules, with or without POA. A small aliquot of each culture is then diluted in an individual well of a replica microplate supplemented with growth medium only. The replica microplate is incubated for $16 \mathrm{~h}$, and the $\mathrm{OD}_{600}$ of a cell culture in each well is measured. For a cell culture in the replica microplate incubated for $16 \mathrm{~h}$ after cell transfer from the master microplate, the value of $\mathrm{OD}_{600}$ is directly proportional to the number of viable cells in a well of the replica microplate. See text for more details. Abbreviation: PCD, programmed cell death. 
impairing functionality and viability of non-cancerous cells. The small molecules exhibiting a combination of these two features have potential to be selective anti-tumor therapeutic agents that cause liponecrotic death of cancer cells, while sparing non-cancerous cells.

A compound library which can be used for the high-throughput screen outlined in Figure 8 may include many small molecules that are currently known to act as follows: (1) to be target-specific activators of Ole1, Tgl1, Tg13, Tg14, Tg15, Yeh1, Yeh2, Dga1, Lro1, Are1 or Are2 in fermenting yeast; and/or (2) to be target-specific inhibitors of Dga1, Are1, Are2, Fox1, Fox2 or Fox3 in fermenting yeast. These target-specific small molecules have been revealed in numerous studies on yeast chemogenomic profiling that have been conducted with the help of haploinsufficiency profiling, homozygous deletion profiling and multicopy gene suppression profiling assays in a high-throughput, genome-wide format [27-29, 31, 252-256].

\section{CONCLUSIONS}

Lipogenesis is a characteristic rewiring of lipid metabolism in cells of various cancers. It consists in channeling the excess metabolites made during aerobic glycolysis into the de novo synthesis of membrane lipids in large quantities. Lipogenesis is one of the key tumorigenic features of cancer cell metabolism, and it is known to play causal roles in certain aspects of cancer initiation, promotion and progression. Recent evidence indicates that lipogenesis is common to cancer cells and rapidly proliferating cells of the yeast $S$. cerevisiae, perhaps because several key processes underlying lipogenesis in these cell types have similar relative rates, exhibit comparable regulation patterns and depend on orthologous proteins. The presently used strategy for the discovery of potential anti-tumor small molecules consists of uncovering pharmaceuticals that inhibit lipogenesis in cancer cells. Emergent evidence suggests that chemical compounds capable of increasing the fatty acid desaturation index of membrane lipids can elicit liponecrotic cell death of both cancer cells and fermenting yeast. This creates an opportunity to use rapidly proliferating yeast as a model organism for a high-throughput screen aimed at the identification of such compounds. The chemical genetic screen proposed here has the potential to develop selective anti-tumor pharmaceuticals that cause liponecrotic death of cancer cells but do not affect functionality and viability of noncancerous cells.

\section{ACKNOWLEDGMENTS}

We are grateful to current and former members of the Titorenko laboratory for discussions. We apologize to those colleagues whose work was not cited owing to space constrains.

\section{FUNDING}

This work was supported by grants from the Natural Sciences and Engineering Research Council (NSERC) of Canada and Concordia University Chair Fund. A.A-C. was supported by Master's Research Scholarship Award from the Fonds québécois de la recherche sur la nature et les technologies (FQRNT). V.S. was supported by the Harriet and Abe Gold Entrance Bursary Award. S.M. was supported by an Undergraduate Summer Award from the NSERC of Canada. V.I.T. is a Concordia University Research Chair in Genomics, Cell Biology and Aging.

\section{CONFLICTS OF INTEREST}

The authors declare no conflict of interest.

\section{REFERENCES}

1. Currie E, Schulze A, Zechner R, Walther TC, Farese RV Jr. Cellular fatty acid metabolism and cancer. Cell Metab. 2013; 18:153-161.

2. Flaveny CA, Griffett K, El-Gendy Bel-D, Kazantzis M, Sengupta M, Amelio AL, Chatterjee A, Walker J, Solt LA, Kamenecka TM, Burris TP. Broad anti-tumor activity of a small molecule that selectively targets the Warburg effect and lipogenesis. Cancer Cell. 2015; 28: 42-56.

3. Galluzzi L, Kepp O, Vander Heiden MG, Kroemer G. Metabolic targets for cancer therapy. Nat Rev Drug Discov. 2013; 12: 829-846.

4. Gorrini C, Harris IS, Mak TW. Modulation of oxidative stress as an anticancer strategy. Nat Rev Drug Discov. 2013; 12: 931-947.

5. Igal RA. Stearoyl-CoA desaturase-1: a novel key player in the mechanisms of cell proliferation, programmed cell death and transformation to cancer. Carcinogenesis. 2010; 31: 1509-1515.

6. Mulvihill MM, Nomura DK. Therapeutic potential of monoacylglycerol lipase inhibitors. Life Sci. 2013; 92: 492497.

7. Piano A, Titorenko VI. The intricate interplay between mechanisms underlying aging and cancer. Aging Dis. 2014; 6: 56-75.

8. Schulze A, Harris AL. How cancer metabolism is tuned for proliferation and vulnerable to disruption. Nature. 2012; 491: 364-373.

9. Vander Heiden MG. Targeting cancer metabolism: a therapeutic window opens. Nat Rev Drug Discov. 2011; 10: 671-684.

10. Zadra G, Photopoulos C, Loda M. The fat side of prostate cancer. Biochim Biophys Acta. 2013; 1831: 1518-1532.

11. Broach JR. Nutritional control of growth and development 
in yeast. Genetics. 2012; 192: 73-105.

12. Cantor JR, Sabatini DM. Cancer cell metabolism: one hallmark, many faces. Cancer Discov. 2012; 2: 881-898.

13. Chantranupong L, Wolfson RL, Sabatini DM. Nutrientsensing mechanisms across evolution. Cell. 2015; 161: 6783.

14. Conrad M, Schothorst J, Kankipati HN, Van Zeebroeck G, Rubio-Texeira M, Thevelein JM. Nutrient sensing and signaling in the yeast Saccharomyces cerevisiae. FEMS Microbiol Rev. 2014; 38: 254-299.

15. Diaz-Ruiz R, Uribe-Carvajal S, Devin A, Rigoulet M. Tumor cell energy metabolism and its common features with yeast metabolism. Biochim Biophys Acta. 2009; 1796: $252-265$

16. Klug L, Daum G. Yeast lipid metabolism at a glance. FEMS Yeast Res. 2014; 14: 369-388.

17. Leontieva OV, Blagosklonny MV. Yeast-like chronological senescence in mammalian cells: phenomenon, mechanism and pharmacological suppression. Aging (Albany NY). 2011; 3: 1078-1091.

18. Lunt SY, Vander Heiden MG. Aerobic glycolysis: meeting the metabolic requirements of cell proliferation. Annu Rev Cell Dev Biol. 2011; 27: 441-464.

19. Natter K, Kohlwein SD. Yeast and cancer cells - common principles in lipid metabolism. Biochim Biophys Acta. 2013; 1831: 314-326.

20. Vander Heiden MG, Cantley LC, Thompson CB. Understanding the Warburg effect: the metabolic requirements of cell proliferation. Science. 2009; 324: 1029-1033.

21. Botstein D, Fink GR. Yeast: an experimental organism for 21st Century biology.

22. Weissman J, Guthrie C, Fink GR (Editors). Guide to Yeast Genetics: Functional Genomics, Proteomics, and Other Systems Analysis. Academic Press, Burlington, 2010, 892 pp.

23. Beaumont TE, Shekhar TM, Kaur L, Pantaki-Eimany D, Kvansakul M, Hawkins CJ. Yeast techniques for modeling drugs targeting Bcl-2 and caspase family members. Cell Death Dis. 2013; 4: e619.

24. Enserink JM. Chemical genetics: budding yeast as a platform for drug discovery and mapping of genetic pathways. Molecules. 2012; 17: 9258-9273.

25. Goldberg AA, Richard VR, Kyryakov P, Bourque SD, Beach A, Burstein MT, Glebov A, Koupaki O, BoukhViner T, Gregg C, Juneau M, English AM, Thomas DY, Titorenko VI. Chemical genetic screen identifies lithocholic acid as an anti-aging compound that extends yeast chronological life span in a TOR-independent manner, by modulating housekeeping longevity assurance processes. Aging (Albany NY). 2010; 2: 393-414.

26. Goldberg AA, Beach A, Davies GF, Harkness TA, Leblanc A, Titorenko VI. Lithocholic bile acid selectively kills neuroblastoma cells, while sparing normal neuronal cells. Oncotarget. 2011; 2: 761-782. doi: 10.18632/ oncotarget. 338 .

27. Hillenmeyer ME, Fung E, Wildenhain J, Pierce SE, Hoon S, Lee W, Proctor M, St Onge RP, Tyers M, Koller D, Altman RB, Davis RW, Nislow C, Giaever G. The chemical genomic portrait of yeast: uncovering a phenotype for all genes. Science. 2008; 320: 362-365.

28. Kapitzky L, Beltrao P, Berens TJ, Gassner N, Zhou C, Wüster A, Wu J, Babu MM, Elledge SJ, Toczyski D, Lokey RS, Krogan NJ. Cross-species chemogenomic profiling reveals evolutionarily conserved drug mode of action. Mol Syst Biol. 2010; 6: 451.

29. Lum PY, Armour CD, Stepaniants SB, Cavet G, Wolf MK, Butler JS, Hinshaw JC, Garnier P, Prestwich GD, Leonardson A, Garrett-Engele P, Rush CM, Bard M, Schimmack G, Phillips JW, Roberts CJ, Shoemaker DD. Discovering modes of action for therapeutic compounds using a genome-wide screen of yeast heterozygotes. Cell. 2004; 116: 121-137.

30. Menacho-Márquez M, Murguía JR. Yeast on drugs: Saccharomyces cerevisiae as a tool for anticancer drug research. Clin Transl Oncol. 2007; 9: 221-228.

31. Parsons AB, Lopez A, Givoni IE, Williams DE, Gray CA, Porter J, Chua G, Sopko R, Brost RL, Ho CH, Wang J, Ketela T, Brenner C, et al. Exploring the mode-of-action of bioactive compounds by chemical-genetic profiling in yeast. Cell. 2006; 126: 611-625.

32. St Onge R, Schlecht U, Scharfe C, Evangelista M. Forward chemical genetics in yeast for discovery of chemical probes targeting metabolism. Molecules. 2012; 17: 13098-13115.

33. Burstein MT, Kyryakov P, Beach A, Richard VR, Koupaki O, Gomez-Perez A, Leonov A, Levy S, Noohi F, Titorenko VI. Lithocholic acid extends longevity of chronologically aging yeast only if added at certain critical periods of their lifespan. Cell Cycle. 2012; 11:3443-3462.

34. Richard VR, Beach A, Piano A, Leonov A, Feldman R, Burstein MT, Kyryakov P, Gomez-Perez A, Arlia-Ciommo A, Baptista S, Campbell C, Goncharov D, Pannu S, Patrinos D, Sadri B, Svistkova V, Victor A, Titorenko VI. Mechanism of liponecrosis, a distinct mode of programmed cell death. Cell Cycle. 2014; 13: 3707-3726.

35. Sheibani S, Richard VR, Beach A, Leonov A, Feldman R, Mattie S, Khelghatybana L, Piano A, Greenwood M, Vali H, Titorenko VI. Macromitophagy, neutral lipids synthesis, and peroxisomal fatty acid oxidation protect yeast from "liponecrosis", a previously unknown form of programmed cell death. Cell Cycle. 2014; 13: 138-147.

36. Galluzzi L, Vitale I, Abrams JM, Alnemri ES, Baehrecke EH, Blagosklonny MV, Dawson TM, Dawson VL, ElDeiry WS, Fulda S, Gottlieb E, Green DR, Hengartner MO, et al. Molecular definitions of cell death subroutines: recommendations of the Nomenclature Committee on Cell Death 2012. Cell Death Differ. 2012; 19: 107-120.

37. Reed JC, Green DR. Apoptosis: Physiology and Pathology. 
Cambridge University Press: New York. 2011; 438 pages.

38. Denton D, Nicolson S, Kumar S. Cell death by autophagy: facts and apparent artefacts. Cell Death Differ. 2012; 19: 87-95.

39. Kroemer G, Levine B. Autophagic cell death: the story of a misnomer. Nat Rev Mol Cell Biol. 2008; 9: 1004-1010.

40. Shen HM, Codogno P. Autophagic cell death: Loch Ness monster or endangered species? Autophagy. 2011; 7: 457465 .

41. Eisenberg T, Büttner S. Lipids and cell death in yeast. FEMS Yeast Res. 2014; 14: 179-197.

42. Eisenberg T, Knauer H, Schauer A, Büttner S, Ruckenstuhl C, Carmona-Gutierrez D, Ring J, Schroeder S, Magnes C, Antonacci L, Fussi H, Deszcz L, Hartl R, et al. Induction of autophagy by spermidine promotes longevity. Nat Cell Biol. 2009; 11: 1305-1314.

43. Eisenberg T, Carmona-Gutierrez D, Büttner S, Tavernarakis N, Madeo F. Necrosis in yeast. Apoptosis. 2010; 15: 257268.

44. Vandenabeele P, Galluzzi L, Vanden Berghe T, Kroemer G. Molecular mechanisms of necroptosis: an ordered cellular explosion. Nat Rev Mol Cell Biol. 2010; 11: 700-714.

45. Beach A, Richard VR, Leonov A, Burstein MT, Bourque SD, Koupaki O, Juneau M, Feldman R, Iouk T, Titorenko VI. Mitochondrial membrane lipidome defines yeast longevity. Aging (Albany NY). 2013; 5: 551-574.

46. Stefan CJ, Manford AG, Emr SD. ER-PM connections: sites of information transfer and inter-organelle communication. Curr Opin Cell Biol. 2013; 25: 434-442.

47 . Tamura Y, Sesaki H, Endo T. Phospholipid transport via mitochondria. Traffic. 2014; 15: 933-945.

48. Tatsuta T, Scharwey M, Langer T. Mitochondrial lipid trafficking. Trends Cell Biol. 2014; 24: 44-52.

49. Goldberg AA, Bourque SD, Kyryakov P, Boukh-Viner T, Gregg C, Beach A, Burstein MT, Machkalyan G, Richard V, Rampersad S, Titorenko VI. A novel function of lipid droplets in regulating longevity. Biochem Soc Trans. 2009; 37: 1050-1055.

50. Henry SA, Kohlwein SD, Carman GM. Metabolism and regulation of glycerolipids in the yeast Saccharomyces cerevisiae. Genetics. 2012; 190: 317-349.

51. Kohlwein SD, Veenhuis M, van der Klei IJ. Lipid droplets and peroxisomes: key players in cellular lipid homeostasis or a matter of fat - store 'em up or burn 'em down. Genetics. 2013; 193: 1-50.

52. Pol A, Gross SP, Parton RG. Review: biogenesis of the multifunctional lipid droplet: lipids, proteins, and sites. J Cell Biol. 2014; 204: 635-646.

53. Kanki T, Wang K, Cao Y, Baba M, Klionsky DJ. Atg32 is a mitochondrial protein that confers selectivity during mitophagy. Dev Cell. 2009; 17: 98-109.

54. Kondo-Okamoto N, Noda NN, Suzuki SW, Nakatogawa
H, Takahashi I, Matsunami M, Hashimoto A, Inagaki F, Ohsumi Y, Okamoto K. Autophagy-related protein 32 acts as autophagic degron and directly initiates mitophagy. J Biol Chem. 2012; 287: 10631-10638.

55. Richard VR, Leonov A, Beach A, Burstein MT, Koupaki O, Gomez-Perez A, Levy S, Pluska L, Mattie S, Rafesh R, Iouk T, Sheibani S, Greenwood M, Vali H, Titorenko VI. Macromitophagy is a longevity assurance process that in chronologically aging yeast limited in calorie supply sustains functional mitochondria and maintains cellular lipid homeostasis. Aging (Albany NY). 2013; 5: 234-269.

56. Feng Y, He D, Yao Z, Klionsky DJ. The machinery of macroautophagy. Cell Res. 2014; 24: 24-41.

57. Reggiori F, Klionsky DJ. Autophagic processes in yeast: mechanism, machinery and regulation. Genetics. 2013; 194: 341-361.

58. Beach A, Leonov A, Arlia-Ciommo A, Svistkova V, Lutchman V, Titorenko VI. Mechanisms by which different functional states of mitochondria define yeast longevity. Int J Mol Sci. 2015; 16: 5528-5554.

59. Carmona-Gutierrez D, Eisenberg T, Büttner S, Meisinger C, Kroemer G, Madeo F. Apoptosis in yeast: triggers, pathways, subroutines. Cell Death Differ. 2010; 17: 763773.

60. Madeo F, Carmona-Gutierrez D, Ring J, Büttner S, Eisenberg T, Kroemer G. Caspase-dependent and caspaseindependent cell death pathways in yeast. Biochem Biophys Res Commun. 2009; 382: 227-231.

61. Ikeda M, Kihara A, Denpoh A, Igarashi Y. The Rim101 pathway is involved in Rsb1 expression induced by altered lipid asymmetry. Mol Biol Cell. 2008; 19: 1922-1931.

62. Kihara A, Igarashi Y. Cross talk between sphingolipids and glycerophospholipids in the establishment of plasma membrane asymmetry. Mol Biol Cell. 2004; 15: 4949-4959.

63. Maeda T. The signaling mechanism of ambient $\mathrm{pH}$ sensing and adaptation in yeast and fungi. FEBS J. 2012; 279: 14071413.

64. Poirier Y, Antonenkov VD, Glumoff T, Hiltunen JK. Peroxisomal beta-oxidation - a metabolic pathway with multiple functions. Biochim Biophys Acta. 2006; 1763: 1413-1426.

65. Wanders RJ. Metabolic functions of peroxisomes in health and disease. Biochimie. 2014; 98:36-44.

66. Diaz-Ruiz R, Rigoulet M, Devin A. The Warburg and Crabtree effects: On the origin of cancer cell energy metabolism and of yeast glucose repression. Biochim Biophys Acta. 2011; 1807: 568-576.

67. Pereira C, Coutinho I, Soares J, Bessa C, Leão M, Saraiva L. New insights into cancer-related proteins provided by the yeast model. FEBS J. 2012; 279: 697-712.

68. Tosato V, Grüning NM, Breitenbach M, Arnak R, Ralser $\mathrm{M}$, Bruschi CV. Warburg effect and translocation-induced genomic instability: two yeast models for cancer cells. Front 
Oncol. 2013; 2: 212.

69. Warburg O, Posener K, Negelein E. Üeber den Stoffwechsel der Tumoren. Biochem Z. 1924; 152: 319-344.

70. Warburg O, Wind F, Negelein E. The metabolism of tumors in the body. J Gen Physiol. 1927; 8: 519-530.

71. Warburg O. On the origin of cancer cells. Science. 1956; 123: 309-314.

72. Cairns RA, Harris IS, Mak TW. Regulation of cancer cell metabolism. Nat Rev Cancer. 2011; 11: 85-95.

73. Crabtree HG. Observations on the carbohydrate metabolism of tumours. Biochem J. 1929; 23: 536-545.

74. Ferreira LM. Cancer metabolism: the Warburg effect today. Exp Mol Pathol. 2010; 89: 372-380.

75. Senyilmaz D, Teleman AA. Chicken or the egg: Warburg effect and mitochondrial dysfunction. F1000Prime Rep. 2015; 7: 41.

76. Sussman I, Erecińska M, Wilson DF. Regulation of cellular energy metabolism: the Crabtree effect. Biochim Biophys Acta. 1980; 591: 209-223.

77. DeBerardinis RJ, Thompson CB. Cellular metabolism and disease: what do metabolic outliers teach us? Cell. 2012; 148: 1132-1144.

78. Hsu PP, Sabatini DM. Cancer cell metabolism: Warburg and beyond. Cell. 2008; 134: 703-707.

79. Dang CV. Links between metabolism and cancer. Genes Dev. 2012; 26: 877-890.

80. DeBerardinis RJ, Lum JJ, Hatzivassiliou G, Thompson CB. The biology of cancer: metabolic reprogramming fuels cell growth and proliferation. Cell Metab. 2008; 7: 11-20.

81. Fritz V, Fajas L. Metabolism and proliferation share common regulatory pathways in cancer cells. Oncogene. 2010; 29: 4369-4377.

82. Soga T. Cancer metabolism: key players in metabolic reprogramming. Cancer Sci. 2013; 104: 275-281.

83. Ward PS, Thompson CB. Metabolic reprogramming: a cancer hallmark even Warburg did not anticipate. Cancer Cell. 2012; 21:297-308.

84. Hue L, Rousseau GG. Fructose 2,6-bisphosphate and the control of glycolysis by growth factors, tumor promoters and oncogenes. Adv Enzyme Regul. 1993; 33: 97-110.

85. Patra KC, Wang Q, Bhaskar PT, Miller L, Wang Z, Wheaton W, Chandel N, Laakso M, Muller WJ, Allen EL, Jha AK, Smolen GA, Clasquin MF, Robey RB, Hay $\mathrm{N}$. Hexokinase 2 is required for tumor initiation and maintenance and its systemic deletion is therapeutic in mouse models of cancer. Cancer Cell. 2013; 24: 213-228.

86. Reibstein D, den Hollander JA, Pilkis SJ, Shulman RG. Studies on the regulation of yeast phosphofructo-1-kinase: its role in aerobic and anaerobic glycolysis. Biochemistry. 1986; 25: 219-227.

87. Bayley JP, Devilee P. The Warburg effect in 2012. Curr Opin Oncol. 2012; 24: 62-67.

88. Chaneton B, Gottlieb E. Rocking cell metabolism: revised functions of the key glycolytic regulator PKM2 in cancer. Trends Biochem Sci. 2012; 37: 309-316.

89. Hamanaka RB, Chandel NS. Cell biology. Warburg effect and redox balance. Science. 2011 Dec 2; 334: 1219-1220.

90. Maitra PK, Lobo Z. A kinetic study of glycolytic enzyme synthesis in yeast. J Biol Chem. 1971; 246: 475-488.

91. Mazurek S. Pyruvate kinase type M2: a key regulator of the metabolic budget system in tumor cells. Int J Biochem Cell Biol. 2011; 43: 969-980.

92. Mazurek S, Boschek CB, Hugo F, Eigenbrodt E. Pyruvate kinase type M2 and its role in tumor growth and spreading. Semin Cancer Biol. 2005; 15: 300-308.

93. Augoff K, Hryniewicz-Jankowska A, Tabola R. Lactate dehydrogenase 5: an old friend and a new hope in the war on cancer. Cancer Lett. 2015 Mar 1; 358: 1-7.

94. Fantin VR, St-Pierre J, Leder P. Attenuation of LDH-A expression uncovers a link between glycolysis, mitochondrial physiology, and tumor maintenance. Cancer Cell. 2006; 9: 425-434.

95. Hohmann S, Cederberg H. Autoregulation may control the expression of yeast pyruvate decarboxylase structural genes PDC1 and PDC5. Eur J Biochem. 1990; 188: 615-621.

96. Van Urk H, Voll WS, Scheffers WA, Van Dijken JP. Transient-state analysis of metabolic fluxes in Crabtreepositive and Crabtree-negative yeasts. Appl Environ Microbiol. 1990; 56: 281-287.

97. Boubekeur S, Bunoust O, Camougrand N, Castroviejo M, Rigoulet M, Guérin B. A mitochondrial pyruvate dehydrogenase bypass in the yeast Saccharomyces cerevisiae. J Biol Chem. 1999; 274: 21044-21048.

98. Gey U, Czupalla C, Hoflack B, Rödel G, Krause-Buchholz $\mathrm{U}$. Yeast pyruvate dehydrogenase complex is regulated by a concerted activity of two kinases and two phosphatases. J Biol Chem. 2008 Apr 11; 283: 9759-9767.

99. Jha MK, Suk K. Pyruvate dehydrogenase kinase as a potential therapeutic target for malignant gliomas. Brain Tumor Res Treat. 2013; 1: 57-63.

100. Moore JD, Staniszewska A, Shaw T, D’Alessandro J, Davis B, Surgenor A, Baker L, Matassova N, Murray J, Macias A, Brough P, Wood M, Mahon PC. VER-246608, a novel pan-isoform ATP competitive inhibitor of pyruvate dehydrogenase kinase, disrupts Warburg metabolism and induces context-dependent cytostasis in cancer cells. Oncotarget. 2014; 5: 12862-12876. doi: 10.18632/ oncotarget.2656.

101. Wigfield SM, Winter SC, Giatromanolaki A, Taylor J, Koukourakis ML, Harris AL. PDK-1 regulates lactate production in hypoxia and is associated with poor prognosis in head and neck squamous cancer. Br J Cancer. 2008; 98 : 1975-1984.

102. Cereghino GP, Atencio DP, Saghbini M, Beiner J, Scheffler IE. Glucose-dependent turnover of the mRNAs encoding succinate dehydrogenase peptides in Saccharomyces cerevisiae: sequence elements in the 5' untranslated region 
of the Ip mRNA play a dominant role. Mol Biol Cell. 1995; 6: 1125-1143.

103. Chatterjee A, Dasgupta S, Sidransky D. Mitochondrial subversion in cancer. Cancer Prev Res (Phila). 2011; 4: 638-654.

104. Cuezva JM, Sánchez-Aragó M, Sala S, Blanco-Rivero A, Ortega AD. A message emerging from development: the repression of mitochondrial beta-F1-ATPase expression in cancer. J Bioenerg Biomembr. 2007; 39: 259-265.

105. Eraso P, Gancedo JM. Catabolite repression in yeasts is not associated with low levels of cAMP. Eur J Biochem. 1984; 141: 195-198.

106. Gottlieb E, Tomlinson IP. Mitochondrial tumour suppressors: a genetic and biochemical update. Nat Rev Cancer. 2005; 5: 857-866.

107. Scheffler IE, de la Cruz BJ, Prieto S. Control of mRNA turnover as a mechanism of glucose repression in Saccharomyces cerevisiae. Int J Biochem Cell Biol. 1998; 30: 1175-1193.

108. Zitomer RS, Nichols DL. Kinetics of glucose repression of yeast cytochrome c. J Bacteriol. 1978; 135: 39-44.

109. Jose C, Bellance N, Rossignol R. Choosing between glycolysis and oxidative phosphorylation: a tumor's dilemma? Biochim Biophys Acta. 2011; 1807: 552-561.

110. Lu J, Tan M, Cai Q. The Warburg effect in tumor progression: mitochondrial oxidative metabolism as an antimetastasis mechanism. Cancer Lett. 2015; 356: 156-164.

111. Rodríguez-Enríquez S, Gallardo-Pérez JC, Avilés-Salas A, Marín-Hernández A, Carreño-Fuentes L, MaldonadoLagunas V, Moreno-Sánchez R. Energy metabolism transition in multi-cellular human tumor spheroids. J Cell Physiol. 2008; 216: 189-197.

112. Rodríguez-Enríquez S, Vital-González PA, FloresRodríguez FL, Marín-Hernández A, Ruiz-Azuara L, Moreno-Sánchez R. Control of cellular proliferation by modulation of oxidative phosphorylation in human and rodent fast-growing tumor cells. Toxicol Appl Pharmacol. 2006; 215: 208-217.

113. Smolková K, Bellance N, Scandurra F, Génot E, Gnaiger E, Plecitá-Hlavatá L, Jezek P, Rossignol R. Mitochondrial bioenergetic adaptations of breast cancer cells to aglycemia and hypoxia. J Bioenerg Biomembr. 2010; 42: 55-67.

114. Baenke F, Peck B, Miess H, Schulze A. Hooked on fat: the role of lipid synthesis in cancer metabolism and tumour development. Dis Model Mech. 2013; 6: 1353-1363.

115. Chauhan N, Visram M, Cristobal-Sarramian A, Sarkleti F, Kohlwein SD. Morphogenesis checkpoint kinase Swe1 is the executor of lipolysis-dependent cell-cycle progression. Proc Natl Acad Sci USA. 2015; 112: E1077- E1085.

116. DeBerardinis RJ, Sayed N, Ditsworth D, Thompson CB. Brick by brick: metabolism and tumor cell growth. Curr Opin Genet Dev. 2008; 18: 54-61.

117. Kurat CF, Wolinski H, Petschnigg J, Kaluarachchi S,
Andrews B, Natter K, Kohlwein SD. Cdk1/Cdc28dependent activation of the major triacylglycerol lipase Tgl4 in yeast links lipolysis to cell-cycle progression. Mol Cell. 2009; 33: 53-63.

118. Loewen CJ. Lipids as conductors in the orchestra of life. F1000 Biol Rep. 2012; 4: 4.

119. Santos CR, Schulze A. Lipid metabolism in cancer. FEBS J. 2012; 279: 2610-2623.

120. Zaidi N, Lupien L, Kuemmerle NB, Kinlaw WB, Swinnen JV, Smans K. Lipogenesis and lipolysis: the pathways exploited by the cancer cells to acquire fatty acids. Prog Lipid Res. 2013; 52: 585-589.

121. Zechner R, Zimmermann R, Eichmann TO, Kohlwein SD, Haemmerle G, Lass A, Madeo F. FAT SIGNALS - lipases and lipolysis in lipid metabolism and signaling. Cell Metab. 2012; 15: 279-291.

122. Clendening JW, Pandyra A, Boutros PC, El Ghamrasni S, Khosravi F, Trentin GA, Martirosyan A, Hakem A, Hakem R, Jurisica I, Penn LZ. Dysregulation of the mevalonate pathway promotes transformation. Proc Natl Acad Sci USA. 2010; 107: 15051-15056.

123. Clendening JW, Penn LZ. Targeting tumor cell metabolism with statins. Oncogene. 2012; 31: 4967-4978.

124. Freed-Pastor WA, Mizuno H, Zhao X, Langerød A, Moon $\mathrm{SH}$, Rodriguez-Barrueco R, Barsotti A, Chicas A, Li W, Polotskaia A, Bissell MJ, Osborne TF, Tian B, et al. Mutant p53 disrupts mammary tissue architecture via the mevalonate pathway. Cell. 2012; 148: 244-258.

125. Liu R, Huang Y. Lipid Signaling in Tumorigenesis. Mol Cell Pharmacol. 2014; 6: 1-9.

126. McCubrey JA, Steelman LS, Chappell WH, Abrams SL, Franklin RA, Montalto G, Cervello M, Libra M, Candido S, Malaponte G, Mazzarino MC, Fagone P, Nicoletti F, et al. Ras/Raf/MEK/ERK and PI3K/PTEN/Akt/mTOR cascade inhibitors: how mutations can result in therapy resistance and how to overcome resistance. Oncotarget. 2012; 3: 1068 1111. doi: 10.18632/oncotarget.659.

127. Thurnher M, Nussbaumer O, Gruenbacher G. Novel aspects of mevalonate pathway inhibitors as antitumor agents. Clin Cancer Res. 2012; 18: 3524-3531.

128. Willemarck N, Rysman E, Brusselmans K, Van Imschoot G, Vanderhoydonc F, Moerloose K, Lerut E, Verhoeven G, van Roy F, Vleminckx K, Swinnen JV. Aberrant activation of fatty acid synthesis suppresses primary cilium formation and distorts tissue development. Cancer Res. 2010; 70: 9453-9462.

129. Yuan TL, Cantley LC. PI3K pathway alterations in cancer: variations on a theme. Oncogene. 2008; 27: 5497-5510.

130. Zunder ER, Knight ZA, Houseman BT, Apsel B, Shokat KM. Discovery of drug-resistant and drug-sensitizing mutations in the oncogenic PI3K isoform p110 alpha. Cancer Cell. 2008; 14: 180-192.

131. Krishnamoorthy S, Honn KV. Eicosanoids in tumor 
progression and metastasis. Subcell Biochem. 2008; 49: 145-168.

132. Mills GB, Moolenaar WH. The emerging role of lysophosphatidic acid in cancer. Nat Rev Cancer. 2003; 3: 582-591.

133. Nomura DK, Long JZ, Niessen S, Hoover HS, Ng SW, Cravatt BF. Monoacylglycerol lipase regulates a fatty acid network that promotes cancer pathogenesis. Cell. 2010; 140: 49-61.

134. Park JB, Lee CS, Jang JH, Ghim J, Kim YJ, You S, Hwang D, Suh PG, Ryu SH. Phospholipase signalling networks in cancer. Nat Rev Cancer. 2012; 12: 782-792.

135. Ren J, Xiao YJ, Singh LS, Zhao X, Zhao Z, Feng L, Rose TM, Prestwich GD, Xu Y. Lysophosphatidic acid is constitutively produced by human peritoneal mesothelial cells and enhances adhesion, migration, and invasion of ovarian cancer cells. Cancer Res. 2006; 66: 3006-3014.

136. Wang MT, Honn KV, Nie D. Cyclooxygenases, prostanoids, and tumor progression. Cancer Metastasis Rev. 2007; 26: 525-534.

137. Yecies JL, Manning BD. Chewing the fat on tumor cell metabolism. Cell. 2010; 140: 28-30.

138. Heusinkveld M, de Vos van Steenwijk PJ, Goedemans R, Ramwadhdoebe TH, Gorter A, Welters MJ, van Hall T, van der Burg SH. M2 macrophages induced by prostaglandin E2 and IL-6 from cervical carcinoma are switched to activated M1 macrophages by CD4+ Th1 cells. J Immunol. 2011; 187: 1157-1165.

139. Joyce JA, Pollard JW. Microenvironmental regulation of metastasis. Nat Rev Cancer. 2009; 9: 239-252.

140. Rolin J, Maghazachi AA. Effects of lysophospholipids on tumor microenvironment. Cancer Microenviron. 2011; 4: 393-403.

141. Santolla MF, Lappano R, De Marco P, Pupo M, Vivacqua A, Sisci D, Abonante S, Iacopetta D, Cappello AR, Dolce V, Maggiolini M. G protein-coupled estrogen receptor mediates the up-regulation of fatty acid synthase induced by $17 \beta$-estradiol in cancer cells and cancer-associated fibroblasts. J Biol Chem. 2012; 287:43234-43245.

142. Chang SH, Liu CH, Conway R, Han DK, Nithipatikom K, Trifan OC, Lane TF, Hla T. Role of prostaglandin E2dependent angiogenic switch in cyclooxygenase 2-induced breast cancer progression. Proc Natl Acad Sci USA. 2004; 101: 591-596.

143. Gao Y, Gao F, Chen K, Tian ML, Zhao DL. Sphingosine kinase 1 as an anticancer therapeutic target. Drug Des Devel Ther. 2015; 9: 3239-3245.

144. Harjes U, Bensaad K, Harris AL. Endothelial cell metabolism and implications for cancer therapy. Br J Cancer. 2012; 107: 1207-1212.

145. Karnezis T, Shayan R, Caesar C, Roufail S, Harris NC, Ardipradja K, Zhang YF, Williams SP, Farnsworth RH, Chai MG, Rupasinghe TW, Tull DL, Baldwin ME, Sloan EK, Fox SB, Achen MG, Stacker SA. VEGF-D promotes tumor metastasis by regulating prostaglandins produced by the collecting lymphatic endothelium. Cancer Cell. 2012; 21: 181-195.

146. Karnezis T, Shayan R, Fox S, Achen MG, Stacker SA. The connection between lymphangiogenic signalling and prostaglandin biology: a missing link in the metastatic pathway. Oncotarget. 2012; 3: 893-906. doi: 10.18632/ oncotarget.593.

147. Nagahashi M, Ramachandran S, Kim EY, Allegood JC, Rashid OM, Yamada A, Zhao R, Milstien S, Zhou H, Spiegel S, Takabe K. Sphingosine-1-phosphate produced by sphingosine kinase 1 promotes breast cancer progression by stimulating angiogenesis and lymphangiogenesis. Cancer Res. 2012; 72: 726-735.

148. Seguin F, Carvalho MA, Bastos DC, Agostini M, Zecchin KG, Alvarez-Flores MP, Chudzinski-Tavassi AM, Coletta RD, Graner E. The fatty acid synthase inhibitor orlistat reduces experimental metastases and angiogenesis in B16-F10 melanomas. Br J Cancer. 2012; 107: 977-987.

149. Das SK, Eder S, Schauer S, Diwoky C, Temmel H, Guertl B, Gorkiewicz G, Tamilarasan KP, Kumari P, Trauner M, Zimmermann R, Vesely P, Haemmerle G, Zechner R, Hoefler G. Adipose triglyceride lipase contributes to cancerassociated cachexia. Science. 2011; 333: 233-238.

150. Martinez-Outschoorn UE, Pestell RG, Howell A, Tykocinski ML, Nagajyothi F, Machado FS, Tanowitz HB, Sotgia F, Lisanti MP. Energy transfer in "parasitic" cancer metabolism: mitochondria are the powerhouse and Achilles' heel of tumor cells. Cell Cycle. 2011; 10: 4208-4216.

151. Nieman KM, Kenny HA, Penicka CV, Ladanyi A, BuellGutbrod R, Zillhardt MR, Romero IL, Carey MS, Mills GB, Hotamisligil GS, Yamada SD, Peter ME, Gwin K, Lengyel E. Adipocytes promote ovarian cancer metastasis and provide energy for rapid tumor growth. Nat Med. 2011; 17: 1498-1503.

152. Nieman KM, Romero IL, Van Houten B, Lengyel E. Adipose tissue and adipocytes support tumorigenesis and metastasis. Biochim Biophys Acta. 2013; 1831: 1533-1541.

153. Nielsen J. Systems biology of lipid metabolism: from yeast to human. FEBS Lett. 2009; 583: 3905-3913.

154. Petranovic D, Tyo K, Vemuri GN, Nielsen J. Prospects of yeast systems biology for human health: integrating lipid, protein and energy metabolism. FEMS Yeast Res. 2010 Dec; 10: 1046-1059.

155. Beckers A, Organe S, Timmermans L, Scheys K, Peeters A, Brusselmans K, Verhoeven G, Swinnen JV. Chemical inhibition of acetyl-CoA carboxylase induces growth arrest and cytotoxicity selectively in cancer cells. Cancer Res. 2007; 67: 8180-8187.

156. Flavin R, Peluso S, Nguyen PL, Loda M. Fatty acid synthase as a potential therapeutic target in cancer. Future Oncol. 2010; 6: 551-562.

157. Mashima T, Sato S, Okabe S, Miyata S, Matsuura M, Sugimoto Y, Tsuruo T, Seimiya H. Acyl-CoA synthetase as 
a cancer survival factor: its inhibition enhances the efficacy of etoposide. Cancer Sci. 2009; 100: 1556-1562.

158. Menendez JA, Lupu R. Fatty acid synthase and the lipogenic phenotype in cancer pathogenesis. Nat Rev Cancer. 2007; 7:763-777.

159. Wakil SJ, Abu-Elheiga LA. Fatty acid metabolism: target for metabolic syndrome. J Lipid Res. 2009; 50: S138-S143.

160. Wang C, Rajput S, Watabe K, Liao DF, Cao D. AcetylCoA carboxylase-alpha as a novel target for cancer therapy. Front Biosci (Schol Ed). 2010; 2: 515-526.

161. Hess D, Chisholm JW, Igal RA. Inhibition of stearoylCoA desaturase activity blocks cell cycle progression and induces programmed cell death in lung cancer cells. PLoS One. 2010; 5: e11394.

162. Minville-Walz M, Pierre AS, Pichon L, Bellenger S, Fèvre C, Bellenger J, Tessier C, Narce M, Rialland M. Inhibition of stearoyl-CoA desaturase 1 expression induces CHOPdependent cell death in human cancer cells. PLoS One. 2010; 5: e14363.

163. Scaglia N, Igal RA. Inhibition of Stearoyl-CoA Desaturase 1 expression in human lung adenocarcinoma cells impairs tumorigenesis. Int J Oncol. 2008; 33: 839-850.

164. Heffernan-Stroud LA, Obeid LM. Sphingosine kinase 1 in cancer. Adv Cancer Res. 2013; 117: 201-235.

165. Ogretmen B, Hannun YA. Biologically active sphingolipids in cancer pathogenesis and treatment. Nat Rev Cancer. 2004; 4: 604-616.

166. Ponnusamy S, Meyers-Needham M, Senkal CE, Saddoughi SA, Sentelle D, Selvam SP, Salas A, Ogretmen B. Sphingolipids and cancer: ceramide and sphingosine-1phosphate in the regulation of cell death and drug resistance. Future Oncol. 2010; 6: 1603-1624.

167. Selvam SP, Ogretmen B. Sphingosine kinase/sphingosine 1-phosphate signaling in cancer therapeutics and drug resistance. Handb Exp Pharmacol. 2013; 216: 3-27.

168. Flavin R, Zadra G and Loda M. Metabolic alterations and targeted therapies in prostate cancer. The Journal of pathology. 2011; 223: 283-294.

169. Rossi S, Graner E, Febbo P, Weinstein L, Bhattacharya N, Onody T, Bubley G, Balk S, Loda M. Fatty acid synthase expression defines distinct molecular signatures in prostate cancer. Mol Cancer Res. 2003; 1: 707-715.

170. Suburu J, Chen YQ. Lipids and prostate cancer. Prostaglandins Other Lipid Mediat. 2012; 98: 1-10.

171. Swinnen JV, Roskams T, Joniau S, Van Poppel H, Oyen R, Baert L, Heyns W, Verhoeven G. Overexpression of fatty acid synthase is an early and common event in the development of prostate cancer. Int J Cancer. 2002; 98: 1922.

172. Cao Z, Fan-Minogue H, Bellovin DI, Yevtodiyenko A, Arzeno J, Yang Q, Gambhir SS, Felsher DW. MYC phosphorylation, activation, and tumorigenic potential in hepatocellular carcinoma are regulated by HMG-CoA reductase. Cancer Res. 2011; 71: 2286-2297.
173. Clem BF, Clem AL, Yalcin A, Goswami U, Arumugam $\mathrm{S}$, Telang S, Trent JO, Chesney J. A novel small molecule antagonist of choline kinase- $\alpha$ that simultaneously suppresses MAPK and PI3K/AKT signaling. Oncogene. 2011; 30: 3370-3380.

174. Corominas-Faja $\mathrm{B}$, Cuyàs $\mathrm{E}$, Gumuzio $\mathrm{J}$, Bosch-Barrera $\mathrm{J}$, Leis O, Martin ÁG, Menendez JA. Chemical inhibition of acetyl-CoA carboxylase suppresses self-renewal growth of cancer stem cells. Oncotarget. 2014; 5: 8306-8316. doi: 10.18632/oncotarget.2059.

175. Marjanovic J, Chalupska D, Patenode C, Coster A, Arnold E, Ye A, Anesi G, Lu Y, Okun I, Tkachenko S, Haselkorn $\mathrm{R}$, Gornicki P. Recombinant yeast screen for new inhibitors of human acetyl-CoA carboxylase 2 identifies potential drugs to treat obesity. Proc Natl Acad Sci USA. 2010; 107 : 9093-9098.

176. Menendez JA. Fine-tuning the lipogenic/lipolytic balance to optimize the metabolic requirements of cancer cell growth: molecular mechanisms and therapeutic perspectives. Biochim Biophys Acta. 2010; 1801: 381-391.

177. Swierczynski J, Hebanowska A, Sledzinski T. Role of abnormal lipid metabolism in development, progression, diagnosis and therapy of pancreatic cancer. World J Gastroenterol. 2014; 20: 2279-2303.

178. Brusselmans K, De Schrijver E, Heyns W, Verhoeven G, Swinnen JV. Epigallocatechin-3-gallate is a potent natural inhibitor of fatty acid synthase in intact cells and selectively induces apoptosis in prostate cancer cells. Int J Cancer. 2003; 106: 856-862.

179. Chang JW, Niphakis MJ, Lum KM, Cognetta AB 3rd, Wang C, Matthews ML, Niessen S, Buczynski MW, Parsons LH, Cravatt BF. Highly selective inhibitors of monoacylglycerol lipase bearing a reactive group that is bioisosteric with endocannabinoid substrates. Chem Biol. 2012; 19: 579-588.

180. Fritz V, Benfodda Z, Rodier G, Henriquet C, Iborra F, Avancès C, Allory Y, de la Taille A, Culine S, Blancou H, Cristol JP, Michel F, Sardet C, Fajas L. Abrogation of de novo lipogenesis by stearoyl-CoA desaturase 1 inhibition interferes with oncogenic signaling and blocks prostate cancer progression in mice. Mol Cancer Ther. 2010; 9: 1740-1754.

181. Kim JH, Lewin TM, Coleman RA. Expression and characterization of recombinant rat Acyl-CoA synthetases 1, 4, and 5. Selective inhibition by triacsin $\mathrm{C}$ and thiazolidinediones. J Biol Chem. 2001; 276: 24667-24673.

182. Lupu R, Menendez JA. Pharmacological inhibitors of fatty acid synthase (FASN)-catalyzed endogenous fatty acid biogenesis: a new family of anti-cancer agents? Curr Pharm Biotechnol. 2006; 7: 483-493.

183. Mashima T, Oh-hara T, Sato S, Mochizuki M, Sugimoto Y, Yamazaki K, Hamada J, Tada M, Moriuchi T, Ishikawa Y, Kato Y, Tomoda H, Yamori T, Tsuruo T. p53-defective tumors with a functional apoptosome-mediated pathway: a new therapeutic target. J Natl Cancer Inst. 2005; 97: 765777. 
184. Mason P, Liang B, Li L, Fremgen T, Murphy E, Quinn A, Madden SL, Biemann HP, Wang B, Cohen A, Komarnitsky S, Jancsics K, Hirth B, Cooper CG, Lee E, Wilson S, Krumbholz R, Schmid S, Xiang Y, Booker M, Lillie J, Carter K. SCD1 inhibition causes cancer cell death by depleting mono-unsaturated fatty acids. PLoS One. 2012; 7: e33823.

185. Orita H, Coulter J, Lemmon C, Tully E, Vadlamudi A, Medghalchi SM, Kuhajda FP, Gabrielson E. Selective inhibition of fatty acid synthase for lung cancer treatment. Clin Cancer Res. 2007; 13: 7139-7145.

186. Roongta UV, Pabalan JG, Wang X, Ryseck RP, Fargnoli J, Henley BJ, Yang WP, Zhu J, Madireddi MT, Lawrence RM, Wong TW, Rupnow BA. Cancer cell dependence on unsaturated fatty acids implicates stearoyl-CoA desaturase as a target for cancer therapy. Mol Cancer Res. 2011; 9: 1551-1561.

187. Sadowski MC, Pouwer RH, Gunter JH, Lubik AA, Quinn RJ, Nelson CC. The fatty acid synthase inhibitor triclosan: repurposing an anti-microbial agent for targeting prostate cancer. Oncotarget. 2014; 5: 9362-9381. doi: 10.18632/ oncotarget.2433.

188. Scaglia N, Chisholm JW, Igal RA. Inhibition of stearoylCoA desaturase-1 inactivates acetyl-CoA carboxylase and impairs proliferation in cancer cells: role of AMPK. PLoS One. 2009; 4: e6812.

189. Van Horn CG, Caviglia JM, Li LO, Wang S, Granger DA, Coleman RA. Characterization of recombinant long-chain rat acyl-CoA synthetase isoforms 3 and 6: identification of a novel variant of isoform 6. Biochemistry. 2005; 44: 16351642.

190. Wang C, Xu C, Sun M, Luo D, Liao DF, Cao D. AcetylCoA carboxylase-alpha inhibitor TOFA induces human cancer cell apoptosis. Biochem Biophys Res Commun. 2009; 385: 302-306.

191. Zhou W, Han WF, Landree LE, Thupari JN, Pinn ML, Bililign T, Kim EK, Vadlamudi A, Medghalchi SM, El Meskini R, Ronnett GV, Townsend CA, Kuhajda FP. Fatty acid synthase inhibition activates AMP-activated protein kinase in SKOV3 human ovarian cancer cells. Cancer Res. 2007; 67: 2964-2971.

192. Göransson O, McBride A, Hawley SA, Ross FA, Shpiro N, Foretz M, Viollet B, Hardie DG, Sakamoto K. Mechanism of action of A-769662, a valuable tool for activation of AMP-activated protein kinase. J Biol Chem. 2007; 282: 32549-32560.

193. Guo D, Hildebrandt IJ, Prins RM, Soto H, Mazzotta MM, Dang J, Czernin J, Shyy JY, Watson AD, Phelps M, Radu CG, Cloughesy TF, Mischel PS. The AMPK agonist AICAR inhibits the growth of EGFRvIII-expressing glioblastomas by inhibiting lipogenesis. Proc Natl Acad Sci USA. 2009; 106: 12932-12937.

194. Jose C, Hébert-Chatelain E, Bellance N, Larendra A, Su M, Nouette-Gaulain K, Rossignol R. AICAR inhibits cancer cell growth and triggers cell-type distinct effects on
OXPHOS biogenesis, oxidative stress and Akt activation. Biochim Biophys Acta. 2011; 1807: 707-718.

195. Leone A, Di Gennaro E, Bruzzese F, Avallone A, Budillon A. New perspective for an old antidiabetic drug: metformin as anticancer agent. Cancer Treat Res. 2014; 159: 355-376.

196. Pollak MN. Investigating metformin for cancer prevention and treatment: the end of the beginning. Cancer Discov. 2012; 2: 778-790.

197. Swinnen JV, Brusselmans K, Verhoeven G. Increased lipogenesis in cancer cells: new players, novel targets. Curr Opin Clin Nutr Metab Care. 2006; 9: 358-365.

198. Steffensen KR. Are synthetic compounds that silence the liver-X-receptor the next generation of anti-cancer drugs? Cancer Cell. 2015; 28:3-4.

199. Kamisuki S, Mao Q, Abu-Elheiga L, Gu Z, Kugimiya A, Kwon Y, Shinohara T, Kawazoe Y, Sato S, Asakura K, Choo HY, Sakai J, Wakil SJ, Uesugi M. A small molecule that blocks fat synthesis by inhibiting the activation of SREBP. Chem Biol. 2009; 16: 882-892.

200. Kamisuki S, Shirakawa T, Kugimiya A, Abu-Elheiga L, Choo HY, Yamada K, Shimogawa H, Wakil SJ, Uesugi M. Synthesis and evaluation of diarylthiazole derivatives that inhibit activation of sterol regulatory element-binding proteins. J Med Chem. 2011; 54: 4923-4927.

201. Williams KJ, Argus JP, Zhu Y, Wilks MQ, Marbois BN, York AG, Kidani Y, Pourzia AL, Akhavan D, Lisiero DN, Komisopoulou E, Henkin AH, Soto H, et al. An essential requirement for the SCAP/SREBP signaling axis to protect cancer cells from lipotoxicity. Cancer Res. 2013; 73: 28502862.

202. Chajès V, Joulin V, Clavel-Chapelon F. The fatty acid desaturation index of blood lipids, as a biomarker of hepatic stearoyl-CoA desaturase expression, is a predictive factor of breast cancer risk. Curr Opin Lipidol. 2011; 22: 6-10.

203. Jeyakumar SM, Lopamudra P, Padmini S, Balakrishna N, Giridharan NV, Vajreswari A. Fatty acid desaturation index correlates with body mass and adiposity indices of obesity in Wistar NIN obese mutant rat strains WNIN/Ob and WNIN/GR-Ob. Nutr Metab (Lond). 2009; 6: 27.

204. Miyazaki M, Kim HJ, Man WC, Ntambi JM. Oleoyl-CoA is the major de novo product of stearoyl-CoA desaturase 1 gene isoform and substrate for the biosynthesis of the Harderian gland 1-alkyl-2,3-diacylglycerol. J Biol Chem. 2001; 276: 39455-39461.

205. Ntambi JM, Miyazaki M. Regulation of stearoyl-CoA desaturases and role in metabolism. Prog Lipid Res. 2004; 43: 91-104.

206. Wang J, Yu L, Schmidt RE, Su C, Huang X, Gould K, Cao G. Characterization of HSCD5, a novel human stearoylCoA desaturase unique to primates. Biochem Biophys Res Commun. 2005; 332: 735-742.

207 . Zhang L, Ge L, Parimoo S, Stenn K, Prouty SM. Human stearoyl-CoA desaturase: alternative transcripts generated from a single gene by usage of tandem polyadenylation 
sites. Biochem J. 1999; 340: 255-264.

208. Dória ML, Cotrim Z, Macedo B, Simões C, Domingues P, Helguero L, Domingues MR. Lipidomic approach to identify patterns in phospholipid profiles and define class differences in mammary epithelial and breast cancer cells. Breast Cancer Res Treat. 2012; 133: 635-648.

209. Dória ML, Cotrim CZ, Simões C, Macedo B, Domingues P, Domingues MR, Helguero LA. Lipidomic analysis of phospholipids from human mammary epithelial and breast cancer cell lines. J Cell Physiol. 2013; 228: 457-468.

210. Guo S, Wang Y, Zhou D, Li Z. Significantly increased monounsaturated lipids relative to polyunsaturated lipids in six types of cancer microenvironment are observed by mass spectrometry imaging. Sci Rep. 2014; 4: 5959.

211. He M, Guo S, Li Z. In situ characterizing membrane lipid phenotype of breast cancer cells using mass spectrometry profiling. Sci Rep. 2015; 5: 11298.

212. AbuAli G, Chaisaklert W, Stelloo E, Pazarentzos E, Hwang MS, Qize D, Harding SV, Al-Rubaish A, Alzahrani AJ, AlAli A, Sanders TA, Aboagye EO, Grimm S. The anticancer gene ORCTL3 targets stearoyl-CoA desaturase-1 for tumour-specific apoptosis. Oncogene. 2015; 34: 1718-1728.

213. Huang GM, Jiang QH, Cai C, Qu M, Shen W. SCD1 negatively regulates autophagy-induced cell death in human hepatocellular carcinoma through inactivation of the AMPK signaling pathway. Cancer Lett. 2015; 358: 180-190.

214. Igal RA. Roles of stearoylCoA desaturase-1 in the regulation of cancer cell growth, survival and tumorigenesis. Cancers (Basel). 2011; 3: 2462-2477.

215. Leung JY, Kim WY. Stearoyl co-A desaturase 1 as a ccRCC therapeutic target: death by stress. Clin Cancer Res. 2013; 19: 3111-3113.

216. Noto A, Raffa S, De Vitis C, Roscilli G, Malpicci D, Coluccia P, Di Napoli A, Ricci A, Giovagnoli MR, Aurisicchio L, Torrisi MR, Ciliberto G, Mancini R. Stearoyl-CoA desaturase-1 is a key factor for lung cancerinitiating cells. Cell Death Dis. 2013; 4: e947.

217. Rysman E, Brusselmans K, Scheys K, Timmermans L, Derua R, Munck S, Van Veldhoven PP, Waltregny D, Daniëls VW, Machiels J, Vanderhoydonc F, Smans K, Waelkens E, Verhoeven G, Swinnen JV. De novo lipogenesis protects cancer cells from free radicals and chemotherapeutics by promoting membrane lipid saturation. Cancer Res. 2010; 70: 8117-8126.

218. von Roemeling CA, Marlow LA, Pinkerton AB, Crist A, Miller J, Tun HW, Smallridge RC, Copland JA. Aberrant lipid metabolism in anaplastic thyroid carcinoma reveals stearoyl CoA desaturase 1 as a novel therapeutic target. J Clin Endocrinol Metab. 2015; 100: E697-E709.

219. von Roemeling CA, Marlow LA, Wei JJ, Cooper SJ, Caulfield TR, Wu K, Tan WW, Tun HW, Copland JA. Stearoyl-CoA desaturase 1 is a novel molecular therapeutic target for clear cell renal cell carcinoma. Clin Cancer Res. 2013; 19: 2368-2380.
220. Ariyama H, Kono N, Matsuda S, Inoue T, Arai H. Decrease in membrane phospholipid unsaturation induces unfolded protein response. J Biol Chem. 2010; 285: 22027-22035.

221. Basseri S, Austin RC. Endoplasmic reticulum stress and lipid metabolism: mechanisms and therapeutic potential. Biochem Res Int. 2012; 2012: 841362.

222. Borradaile NM, Han X, Harp JD, Gale SE, Ory DS, Schaffer JE. Disruption of endoplasmic reticulum structure and integrity in lipotoxic cell death. J Lipid Res. 2006; 47: 2726-2737.

223. Deguil J, Pineau L, Rowland Snyder EC, Dupont S, Beney L, Gil A, Frapper G, Ferreira T. Modulation of lipidinduced ER stress by fatty acid shape. Traffic. 2011; 12 : 349-362.

224. Erbay E, Babaev VR, Mayers JR, Makowski L, Charles KN, Snitow ME, Fazio S, Wiest MM, Watkins SM, Linton MF, Hotamisligil GS. Reducing endoplasmic reticulum stress through a macrophage lipid chaperone alleviates atherosclerosis. Nat Med. 2009; 15: 1383-1391.

225. Hou NS, Gutschmidt A, Choi DY, Pather K, Shi X, Watts JL, Hoppe T, Taubert S. Activation of the endoplasmic reticulum unfolded protein response by lipid disequilibrium without disturbed proteostasis in vivo. Proc Natl Acad Sci USA. 2014; 111: E2271-E2280.

226. Kitai Y, Ariyama H, Kono N, Oikawa D, Iwawaki T, Arai H. Membrane lipid saturation activates IRE1 $\alpha$ without inducing clustering. Genes Cells. 2013; 18: 798-809.

227. Volmer R, van der Ploeg K, Ron D. Membrane lipid saturation activates endoplasmic reticulum unfolded protein response transducers through their transmembrane domains. Proc Natl Acad Sci USA. 2013; 110: 4628-4633.

228. Wang D, Wei Y, Pagliassotti MJ. Saturated fatty acids promote endoplasmic reticulum stress and liver injury in rats with hepatic steatosis. Endocrinology. 2006; 147: 943951.

229. Wei Y, Wang D, Topczewski F, Pagliassotti MJ. Saturated fatty acids induce endoplasmic reticulum stress and apoptosis independently of ceramide in liver cells. Am J Physiol Endocrinol Metab. 2006; 291: E275-E281.

230. Ashcraft BA, Fillers WS, Augustine SL, Clarke SD. Polymer-protomer transition of acetyl-CoA carboxylase occurs in vivo and varies with nutritional conditions. J Biol Chem. 1980; 255: 10033-10035.

231. Clarke SD, Salati LM. Fatty acid-mediated disaggregation of acetyl-CoA carboxylase in isolated liver cells. Fed Proc. 1985; 44: 2458-2462.

232. Goodridge AG. Regulation of the activity of acetyl coenzyme A carboxylase by palmitoyl coenzyme A and citrate. J Biol Chem. 1972; 247: 6946-6952.

233. Krycer JR, Sharpe LJ, Luu W, Brown AJ. The Akt-SREBP nexus: cell signaling meets lipid metabolism. Trends Endocrinol Metab. 2010; 21: 268-276.

234. Györfy Z, Benkö S, Kusz E, Maresca B, Vígh L, Duda E. Highly increased TNF sensitivity of tumor cells expressing 
the yeast delta 9-desaturase gene. Biochem Biophys Res Commun. 1997; 241: 465-470.

235. Györfy Z, Horváth I, Balogh G, Domonkos A, Duda E, Maresca B, Vígh L. Modulation of lipid unsaturation and membrane fluid state in mammalian cells by stable transformation with the delta9-desaturase gene of Saccharomyces cerevisiae. Biochem Biophys Res Commun. 1997; 237: 362-366.

236. Stukey JE, McDonough VM, Martin CE. Isolation and characterization of OLE1, a gene affecting fatty acid desaturation from Saccharomyces cerevisiae. J Biol Chem. 1989; 264: 16537-16544.

237. Petschnigg J, Wolinski H, Kolb D, Zellnig G, Kurat CF, Natter K, Kohlwein SD. Good fat, essential cellular requirements for triacylglycerol synthesis to maintain membrane homeostasis in yeast. J Biol Chem. 2009; 284: 30981-30993.

238. Arlia-Ciommo A, Piano A, Svistkova V, Mohtashami S, Titorenko VI. Mechanisms underlying the anti-aging and anti-tumor effects of lithocholic bile acid. Int J Mol Sci. 2014; 15:16522-16543.

239. Beach A, Richard VR, Bourque S, Boukh-Viner T, Kyryakov P, Gomez-Perez A, Arlia-Ciommo A, Feldman R, Leonov A, Piano A, Svistkova V, Titorenko VI. Lithocholic bile acid accumulated in yeast mitochondria orchestrates a development of an anti-aging cellular pattern by causing age-related changes in cellular proteome. Cell Cycle. 2015; 14: 1643-1656.

240. Beach A, Titorenko VI. In search of housekeeping pathways that regulate longevity. Cell Cycle. 2011; 10: 3042-3044.

241. Burstein MT, Titorenko VI. A mitochondrially targeted compound delays aging in yeast through a mechanism linking mitochondrial membrane lipid metabolism to mitochondrial redox biology. Redox Biol. 2014; 2: 305-307.

242. Goldberg AA, Titorenko VI, Beach A, Sanderson JT. Bile acids induce apoptosis selectively in androgen-dependent and -independent prostate cancer cells. PeerJ. 2013; 1: e122.

243. Hanahan D, Weinberg RA. Hallmarks of cancer: the next generation. Cell. 2011; 144: 646-674.

244. Kaeberlein M. Longevity and aging. F1000Prime Rep. 2013; 5: 5 .

245. Niccoli T, Partridge L. Ageing as a risk factor for disease. Curr Biol. 2012; 22: R741-R752.

246. Partridge L. Intervening in ageing to prevent the diseases of ageing. Trends Endocrinol Metab. 2014; 25: 555-557.

247. Blagosklonny MV. Aging and immortality: quasiprogrammed senescence and its pharmacologic inhibition. Cell Cycle. 2006; 5: 2087-2102.

248. Blagosklonny MV, Hall MN. Growth and aging: a common molecular mechanism. Aging (Albany NY). 2009; 1: 357 362.

249. Campisi J. Aging, cellular senescence, and cancer. Annu Rev Physiol. 2013; 75: 685-705.

250. López-Otín C, Blasco MA, Partridge L, Serrano M,
Kroemer G. The hallmarks of aging. Cell. 2013; 153: 11941217.

251. Rodier F, Campisi J. Four faces of cellular senescence. J Cell Biol. 2011; 192: 547-556.

252. Giaever G, Flaherty P, Kumm J, Proctor M, Nislow C, Jaramillo DF, Chu AM, Jordan MI, Arkin AP, Davis RW. Chemogenomic profiling: identifying the functional interactions of small molecules in yeast. Proc Natl Acad Sci USA. 2004; 101: 793-798.

253. Hoepfner D, Helliwell SB, Sadlish H, Schuierer S, Filipuzzi I, Brachat S, Bhullar B, Plikat U, Abraham Y, Altorfer M, Aust T, Baeriswyl L, Cerino R, et al. High-resolution chemical dissection of a model eukaryote reveals targets, pathways and gene functions. Microbiol Res. 2014; 169: 107-120.

254. Hoon S, Gebbia M, Costanzo M, Davis RW, Giaever G, Nislow C. A global perspective of the genetic basis for carbonyl stress resistance. G3 (Bethesda). 2011; 1: 219-231.

255. Luesch H, Wu TY, Ren P, Gray NS, Schultz PG, Supek F. A genome-wide overexpression screen in yeast for smallmolecule target identification. Chem Biol. 2005; 12: 55-63.

256. Roemer T, Xu D, Singh SB, Parish CA, Harris G, Wang H, Davies JE, Bills GF. Confronting the challenges of natural product-based antifungal discovery. Chem Biol. 2011; 18: 148-164. 